\title{
Stones in Motion: Cost units to understand flint procurement strategies during the Upper Palaeolithic in the south-western Pyrenees using GIS
}

\author{
Alejandro Prieto, Maite García-Rojas, Aitor Sánchez, Aitor Calvo, Eder \\ Domínguez-Ballesteros, Javier Ordoño, Maite Iris García-Collado
}

\begin{abstract}
Department of Geography, Prehistory and Archaeology. Faculty of Arts, University of the Basque Country. Tomás y Valiente Street N/N, Vitoria-Gasteiz, Spain.

Email: Prieto: alejandro.prieto@ehu.es; García-Rojas: maitensx@gmail.com; Sánchez: aitor.sanchezl@ehu.es; Calvo: aitor.calvo@ehu.es; Domínguez-Ballesteros: eder.dominguez@ehu.es; Ordoño: javier.ordono@ehu.es;

García-Collado: maiteiris.garcia@ehu.es
\end{abstract}

\begin{abstract}
:
Studies on lithic resource management -mainly flint- by prehistoric groups south of the western Pyrenees have significantly increased during the past decades. These studies usually focus on identifying outcrops and characterising the different varieties found at archaeological sites. However, the understanding of mobility and territorial management patterns based on raw materials is still very limited and has only been tackled in terms of lineal distance.

This paper proposes a methodological approach for the territorial analysis of flint distribution with the three following aims: 1) to determine the expansion ranges of each variety of flint from its outcrop; 2) to spatially relate these outcrops with archaeological sites; and 3) to improve our knowledge on the catchment strategies of Upper Palaeolithic groups.

The methodological tool chosen to fulfil these objectives is the Geographic Information System (GIS), because it allows to relate spatially the flint outcrops and flint varieties identified at archaeological sites based on: 1) isocost maps showing the cost of expansion for each variety of flint across the territory built on topography; 2) the quantification of the cost of expansion using Cost Units (CU); and 3) the relationship between the percentage of each variety of flint at each archaeological site and the cost of accessing its outcrop. In order to demonstrate that cost is a powerful way to relate spatially raw material distribution and archaeological sites with outcrops, we contrasted its results with the ones obtained by more classic means (Euclidean distance and distance across the most optimal route). It was therefore shown that cost is better at explaining the spatial relationship between flint outcrops and archaeological sites, which, in turn, provides new data on catchment strategies, mobility patterns and territorial management of Upper Palaeolithic groups.
\end{abstract}

Keywords: Upper Palaeolithic; South-Western Pyrenees; flint procurement; GIS; cost; territorial management; mobility patterns

Published by the School of History, Classics and Archaeology, University of Edinburgh ISSN: 2055-0472. URL: http://journals.ed.ac.uk/lithicstudies/

This work is licensed under a Creative Commons Attribution 2.5 UK: Scotland License. 
A. Prieto et al.

\section{Introduction}

Despite the progress made in recent years, only a few aspects of the macrospatial behaviour of Palaeolithic societies are known and information about the decisions and determining factors that led these groups to settle or move across the landscape is still scarce. Fortunately, the increasing interest in palaeogeographic analyses, the development of new theoretical models, the application of new techniques (e.g., palaeoenvironmental, stable isotope or archaeopetrological studies) and the progressive addition of new computational tools to process geographic information, have enabled new perspectives on Palaeolithic territorial patterns to emerge as a result (Kelly 1995; Binford 2001; Burke 2004; Vialou 2005; Whallon 2006; Hamilton et al. 2007; Geneste et al. 2008; Grove 2009).

Following this trend, the study of lithic raw materials has attracted most of the efforts of archaeologists seeking to characterize the procurement and management of lithic raw resources, the articulation of economic territories and the mobility patterns of Palaeolithic groups (Sarabia 1995; Terradas 2002; Mangado 2006; Djindjian 2009). The precise location and petrological characterisation of the main procurement sources (mostly flint) has recently taken a great step forward. This has enabled the identification of long-distance economic links between settlement and outcrops (Geneste \& Rigaud 1977; Demars 1982; Arias 1992; Close 1996; Simonnet 1996; Bernabeu et al. 1998; Djindjian et al. 1999; Bourguignon \& Turq 2008; Corchón et al. 2009). On the southern slope of the western Pyrenees, the area on which this study focuses on, research carried out by A. Tarriño over the past several years has been especially important (Tarriño 2006; Tarriño et al. 2007a; Tarriño et al. 2007b; Tarriño 2011a; b; Tarriño et al. 2013; Tarriño \& Elorrieta 2013; Tarriño et al. 2015).

As a result of these studies, there is an increasingly bigger "map of dots and arrows", where these connections are shown linearly, sometimes categorized according to the percentages of the different flint varieties found. In our opinion, these analyses do not adequately address the geographic constraints that conditioned Palaeolithic groups and they do not represent the actual possible routes taken by them. Therefore, this classic approach cannot explain the reasons behind the variations observed in the types of flint used.

The use of Geographic Information Systems (henceforth GIS) to model the mobility of human groups has a long tradition in the archaeological research of the Iberian Peninsula, with a special focus on the Holocene (Fairén 2004; Fábrega \& Parcero 2007; Murrieta-Flores et al. 2009; Parcero et al. 2009; Murrieta-Flores 2010; Llobera et al. 2011; Güimil-Fariña \& Parcero-Oubiña 2015). This tool is not commonly used in Palaeolithic studies, either because research has focused on other topics, or because of the difficulty of adapting this methodology to a much less visible record on a macro scale. Nevertheless, excellent studies integrating this tool (using optimal routes) with concepts such as accessibility or cost and applied to the study of settlement patterns (García 2010; Turrero et al. 2013) or the management of faunal resources (Coward 2004; Marín 2008) have recently been published for the Cantabrian Region.

In the case of lithic resource procurement, its application is even more innovative, as shown by the pilot studies carried out on the Portuguese valley of Foz Côa (Aubry et al. 2012), the valleys of the Trubia river in Asturias (Fernández 2010) or the Asón in Cantabria (Rissetto 2009; 2012). These works, pioneers in our area of study, deepen into the modelling of operational mobility based on optimal routes and have allowed us to obtain highly interesting, yet provisional, conclusions on the management of lithic resources by Palaeolithic groups. However, optimal route approaches (e.g., Least Cost Path analyses) are usually limited to determine the shortest line between two places, ignoring the fact that multiple paths can actually connect two spots and that choosing one or another will depend on several factors different from linear distance. 
The present study makes a case for the usefulness of the 'cost' concept in the analysis and interpretation of raw material provisioning/sourcing by prehistoric human groups as an alternative to Euclidean distance or the identification of optimal routes. In order to do so, we suggest an approach based on orography and developed using digital cartographic analysis tools such as GIS (van Leusen 2002; Wheatley \& Gillings 2002; Connolly \& Lake 2006; White \& Surface-Evans 2012). As a first case study, this paper focuses on the Upper Palaeolithic of the southern region of the western Pyrenees and seeks to fulfil the following objectives:

- To determinate and compare the ranges of expansion of the three main flint types, using three different measurement sets, obtained from the application of Least Cost Analysis (LCA) through GIS.

- To determinate which of these three measurement suggestions best fits the archaeological record.

- To bring back orography as a key factor to understanding Palaeolithic mobility. In this way, we may be able to identify constraining transit areas or high-mobility transit zones that affected the movement of Palaeolithic societies.

\section{Context and materials}

The geographic framework chosen for this case study are the south western foothills of the Pyrenees, delimited by the Cantabrian Sea to the north, the Ebro Basin to the south, the estuary of Bilbao to the west and the Bidasoa valley to the east. This area corresponds to the current Spanish Autonomous Regions of Euskadi, Navarre and a small part of the province of Burgos. This area is part of the natural corridor formed by the foothills of the western Pyrenees (Figure 1) and is an appropriate geographical framework for the present research for the following reasons:

1. It is a natural crossing area between the European continent and the Iberian Peninsula, where intense mobility of Upper Palaeolithic groups has already been noted (Arrizabalaga 2007; 2009; Arrizabalaga \& Iriarte-Chiapusso 2010a; b; Arrizabalaga et al. 2013; Arrizabalaga et al. 2014).

2. Both watersheds of the western Pyrenees show a significantly high density of highquality flint outcrops extensively exploited during the Palaeolithic.

3. This is a region with a highly variable orography.

4. Detailed digital cartographic information is available for the study region.

Within this framework, we chose the three outcrops corresponding to the most common flint varieties known for the Upper Palaeolithic (Tarriño 2006). These are:

1. Kurtzia Flysch flint (Barrika, Bizkaia): This variety outcrops in an olistostrome 40 metres deep pertaining to the Eibar Formation (Mathey 1982). The nature of this type of outcrop allows weathering agents to easily free flint blocks from it, placing them in the marine influence area. This variety is bioclastic with many sponge spicules, detrital quartz and moldic microporosity from the dissolution of dolomite crystals (Tarriño 2006: 64-67).

2. Treviño flint (Treviño, Burgos): This variety outcrops in the Araico-Cucho mountain range, which is formed by Miocene lacustrine-palustrine limestone and contains plenty of nodular and stratiform silicifications. There are four main varieties: two bioclastic nodular (gastropods and ostracods) -one of them micritic, with liesegang rings, and the other rich in organic content-, and two stratiform -a brecciated silcrete with ooidal texture and siliceous cementations and a micritic one with algal lamination- (Tarriño 2006: 86-92).

3. Urbasa flint (Urbasa, Navarra): These are Thanetian (Paleocene) silicifications located in the SD-6 depositional sequence of the Urbasa mountain range (Baceta 1996: 120-133). This flint is composed of microquartz, benthic foraminifera (Nummulites heberti and 
Discocyclina seunesi) and fragments of echinoderms. Its colour is dark and morphology nodular, sometimes slightly botryoidal (Tarriño et al. 2007b).

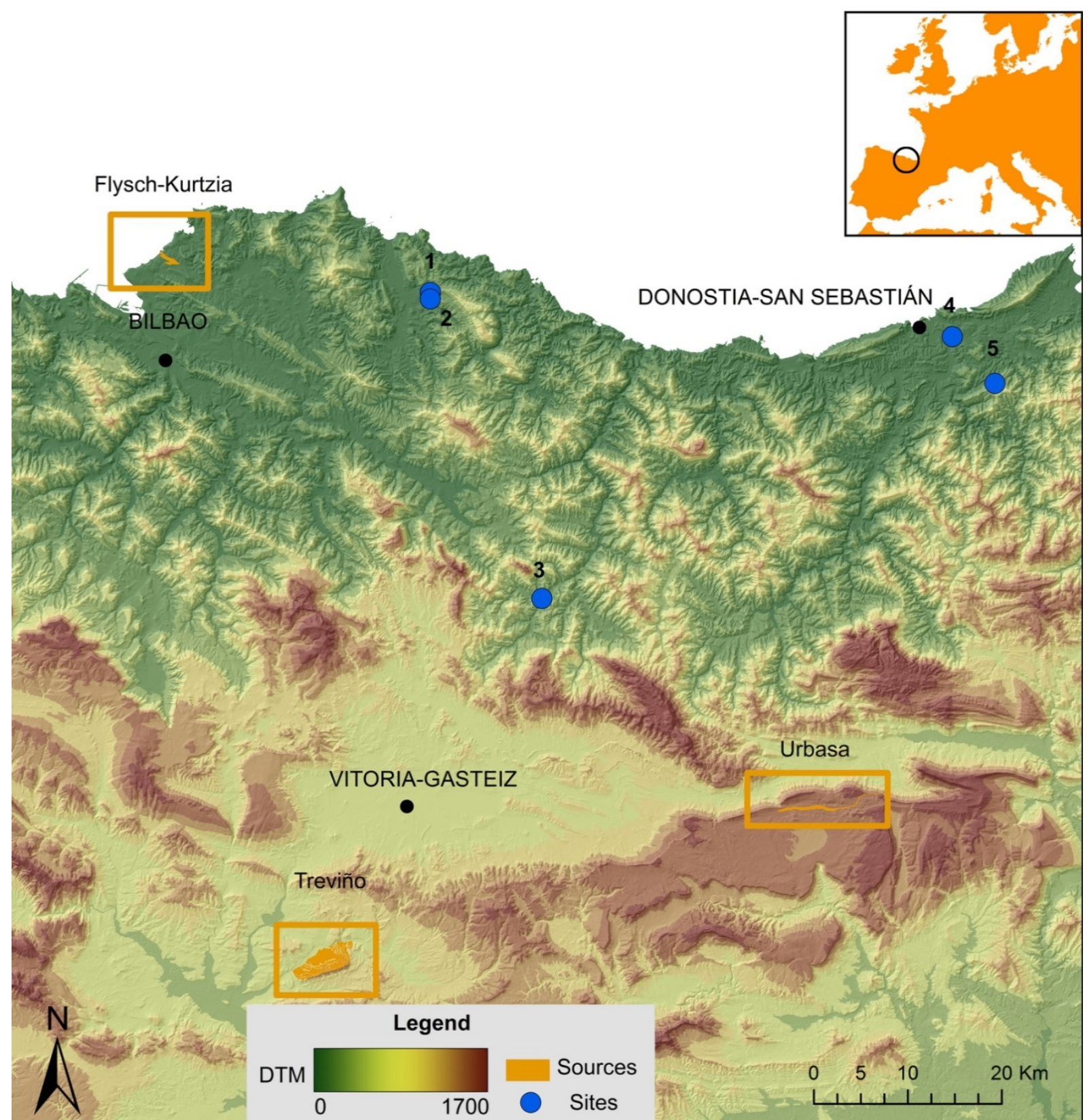

Figure 1. Digital elevation model showing the location of the archaeological sites and geological outcrops in the area of study. Archaeological sites: 1. Antoliñako Koba, 2. Santimamiñe, 3. Labeko Koba, 4. Ametzagaina and 5. Aitzbitarte III.

Likewise, for the present study we chose Upper Palaeolithic archaeological sites in the region that had already been studied in terms of the origin of the lithic raw materials and where the flint varieties mentioned above had been identified. The sites are:

1. Aitzbitarte III (Rentería, Gipuzkoa): This cave was excavated by J. M. de Barandiarán from 1961 to 1965 and re-excavated by J. Altuna between 1986 and 2002. It has an important sequence running from the Early Upper Palaeolithic. It presents a level with Aurignacoid and Mousteroid industries ( $\mathrm{Vb}$ base) at the bottom, on which there is an Evolved Aurignacian level (Vb central) and four Gravettian levels (Vb superior, Va, IV and III), from both the early 
and late phases. At the top, a level between the Gravettian and the Middle Solutrean (II) and a level attributed to an indeterminate Upper Palaeolithic (I) were noted (Altuna et al. 2011).

2. Ametzagaina (Donostia-San Sebastián, Gipuzkoa): This open-air campsite was excavated by J. Tapia between 2007 and 2009. Two main lithic assemblages (East and West) were recovered. A large part of them was found on the surface. The East assemblage was entirely attributed to the Gravettian, whereas the West assemblage, being also Gravettian, probably has intrusions from the Evolved Aurignacian. One of the pits excavated (Pit 7) revealed the existence of a stratigraphic relict, where a level with industry from the same Gravettian facies was recorded (Tapia et al. 2009; Calvo 2012; Calvo et al. 2013).

3. Antoliñako Koba (Gauteguiz-Arteaga, Bizkaia): This cave, initially explored by J. M. de Barandiarán in 1923, was excavated by M. Aguirre between 1995 and 2008. It contains a deep stratigraphy covering the whole of the Upper Palaeolithic; from the Evolved Aurignacian level at the base (Lmbk inf/Smk), to the Upper Magdalenian/Azilian (Lanc) at the top. The intermediate section of the sequence is noteworthy, especially the levels dated back to the Early (Lmbk sup) and Late (Lab) Gravettian and to the Upper Solutrean (Lmc). Above this level there is another modest one pertaining to the Evolved Lower Magdalenian (Lgc sup) (Aguirre 2000; 2012).

4. Labeko Koba (Arrasate, Gipuzkoa): This cave, now destroyed, was completely excavated during a rescue archaeological excavation in 1988, under the direction of A. Arrizabalaga. The site preserved one of the most important stratigraphies in the Iberian Peninsula for the beginning of the Upper Palaeolithic. The sequence comprised, from bottom to top, a Châtelperronian level (IX inferior), a Protoaurignacian one (VII), three levels pertaining to the Early Aurignacian (VI, V and IV) and a last level of uncertain nature, maybe related to the final episodes of the Aurignacian (III) (Arrizabalaga \& Altuna 2000).

5. Santimamiñe (Kortezubi, Bizkaia): This famous rock art sanctuary from the Middle Magdalenian underwent three main excavations: from 1918 to 1926 by J. M. de Barandiarán, T. Aranzadi and E. Eguren; from 1960 to 1962 by J. M. de Barandiarán; and, finally, from 2004 to 2012 by J. C. López Quintana. According to the data obtained during its first excavation, the deep stratigraphic sequence spans, without interruption, from the Early Upper Palaeolithic (level IX, Aurignacian) to the Roman period (level 1a). The Palaeolithic occupation is represented by the aforementioned Aurignacian level at the bottom and by successive Gravettian (VIII), Solutrean (VII) and Magdalenian (VI) levels (Barandiarán 1976). The last excavation of the innermost sector of the entrance revealed the existence of a Late Lower Magdalenian (Csn-Camr), a Middle/Upper Magdalenian? (Almp), a Final Upper Magdalenian (Slnc) and an Azilian levels (Arcp) (López Quintana 2011).

The data on the raw material distribution at these sites are shown in the following table (Table 1). The percentage of each flint variety was obtained from the bibliography available. Total number of stone pieces is shown in the table, including other raw materials and flint varieties not considered in this paper, as well as unknown flint varieties. Percentage were calculated taking into account the total number of stone pieces from each archaeological level and the quantity of each flint variety.

\section{Methodology}

For this research study we used the spatial analysis tools offered by the ArcGIS 10.2 software and the Digital Elevation Model (MDT25, following the Spanish acronym) developed by the Spanish National Institute of Geography (IGN 2014). All the data included in this study were georeferenced following the UTM-ETRS89 (zone 30N) system of projected coordinates. 
We did not consider bathymetry due its limitations when applied to the past, although we know it could have provided very interesting data on currently submerged Palaeolithic shore and lowlands. The main problem in this respect is access to data, the fluctuations of the sealevel and the differential erosion of its surfaces, which could distort the results of this study. The fact that our spatial analysis deals with current landscape features instead of actual Palaeolithic orography is another limitation, but we consider high-resolution digital cartography is still the best source for our approach. Finally, we are also aware effort or cost cannot only be quantified through geographic variables, but we consider these are the only ones based on consistent data we have access to nowadays. Factors such as vegetation, lithology, the river system or climate constraints could have greatly influenced the mobility of Palaeolithic groups, but being unable to know their exact impact at each period prevents us from including them systematically. Bearing these biases in mind, these are the steps we followed:

Table 1. Raw data of the sites and the archaeological levels included in the study. An asterisk indicates the identification is only probable, since it was not easy to distinguish the Flysch variety of Kurtzia from the other Flysch varieties available in the region. Only cases where the Flysch flint identification is specified in the bibliography are listed.

\begin{tabular}{|c|c|c|c|c|c|c|c|}
\hline \multirow[b]{2}{*}{ Site } & \multirow[b]{2}{*}{ Level } & \multirow[b]{2}{*}{$\begin{array}{l}\text { Chrono-cultural } \\
\text { attribution }\end{array}$} & \multirow{2}{*}{$\begin{array}{c}\text { No. } \\
\text { stone } \\
\text { pieces }\end{array}$} & \multicolumn{3}{|c|}{ Flint varieties (\%) } & \multirow[b]{2}{*}{ References } \\
\hline & & & & $\begin{array}{l}\text { Flysch } \\
\text { Kurtzia }\end{array}$ & Urbasa & Treviño & \\
\hline \multirow{6}{*}{ Aitzbitarte III } & $\mathrm{Vb}$ base & $\begin{array}{l}\text { Mousterian- } \\
\text { Aurignacian }\end{array}$ & 46 & $0^{*}$ & 0 & 0 & Tarriño 2011 \\
\hline & $\mathrm{Vb}$ & Evolved Aurignacian & 850 & $0 *$ & 6.4 & 0.8 & Tarriño 2011 \\
\hline & Vb sup & Early Gravettian & 165 & $0 *$ & 9.1 & 1.8 & Tarriño 2011 \\
\hline & Va & Early Gravettian & 358 & $0 *$ & 10.9 & 0.6 & Tarriño 2011 \\
\hline & IV & Early Gravettian & 222 & $0 *$ & 19.8 & 0.5 & Tarriño 2011 \\
\hline & III & Recent Gravettian & 356 & $0 *$ & 16.3 & 0.6 & Tarriño 2011 \\
\hline \multirow{3}{*}{$\begin{array}{l}\text { Antoliñako } \\
\text { koba }\end{array}$} & $\begin{array}{l}\text { Lab/Lmbk } \\
\text { sup/Lmbk inf }\end{array}$ & Gravettian & 224 & 75 & 10.3 & 4.9 & $\begin{array}{l}\text { Tarriño } 2006 \\
(137-144)\end{array}$ \\
\hline & Lmc & Solutrean & 415 & 58.3 & 9.9 & 20.7 & $\begin{array}{l}\text { Tarriño } 2006 \\
(137-144)\end{array}$ \\
\hline & $\begin{array}{l}\text { Lgc/Lamc/ } \\
\text { Lanc }\end{array}$ & Magdalenian & 77 & 79.2 & 6.5 & 9.1 & $\begin{array}{l}\text { Tarriño } 2006 \\
(137-144)\end{array}$ \\
\hline \multirow{6}{*}{ Labeko Koba } & IX inf & Chatelperronian & 68 & 36.8 & 26.5 & 19.1 & Tarriño 2000 \\
\hline & VII & Proto-Aurignacian & 1.422 & 7 & 65.5 & 23.3 & Tarriño 2000 \\
\hline & VI & Early Aurignacian & 95 & 8.5 & 35.1 & 42.6 & Tarriño 2000 \\
\hline & V & Early Aurignacian & 1.358 & 1.5 & 51.8 & 36.5 & Tarriño 2000 \\
\hline & IV & Early Aurignacian & 875 & 1.8 & 33.7 & 43 & Tarriño 2000 \\
\hline & III & Early Aurignacian? & 51 & 90.2 & 3.9 & 5.9 & Tarriño 2000 \\
\hline \multirow{2}{*}{ Santimamiñe } & Csn-Camr & Lower Magdalenian & 92 & 68.5 & 5.4 & 3.3 & Tarriño 2011 \\
\hline & Arcp & Azilian & 144 & 82.6 & 4.2 & 0 & Tarriño 2011 \\
\hline \multirow{2}{*}{ Ametzagaina } & $\begin{array}{l}\text { Eastern } \\
\text { Assemblage }\end{array}$ & Gravettian & 2.029 & 1 & 4 & 0 & $\begin{array}{l}\text { Arrizabalaga } \\
\text { et al. } 2014\end{array}$ \\
\hline & $\begin{array}{l}\text { Western } \\
\text { Assemblage }\end{array}$ & $\begin{array}{l}\text { Evolved Aurignacian- } \\
\text { Gravettian }\end{array}$ & 932 & 0* & 1 & 0 & $\begin{array}{l}\text { Arrizabalaga } \\
\text { et al. } 2014\end{array}$ \\
\hline
\end{tabular}

First, after having merged all the MDT25 sheets covering the territory under study, we created a slope map, measured in degrees, using the Slope tool (Figure 2.a). Next, this map was reclassified with the Reclass tool. The values of the cells of the new raster output were calculated by assigning average subunits of cost to the movement between specific slope ranges (Figure 2.b). This calculation was based on the model developed by M. Llobera (2000) after A. E. Minnetti’s experiments (Minnetti 1995) (see also López Romero, (2005)). 
However, it is worth mentioning there are other valid approaches to calculate the cost of moving, such as those of Pandolf (1977), Langmuir (1984: 35) or Tobler (1993), whose most recent adaptations (Marín 2009; Kramer 2010) are currently being debated (Kantner 2012). The method chosen for this study defines the unitary value of cost as the effort generated by moving at a constant speed of $5 \mathrm{~km} / \mathrm{h}$ on a $0^{\circ}$ slope (Figure 2.c). As a result, we obtained a new surface friction map where each pixel contains information on the effort required to cross it, expressed in subunits of cost (Figure 2.d).

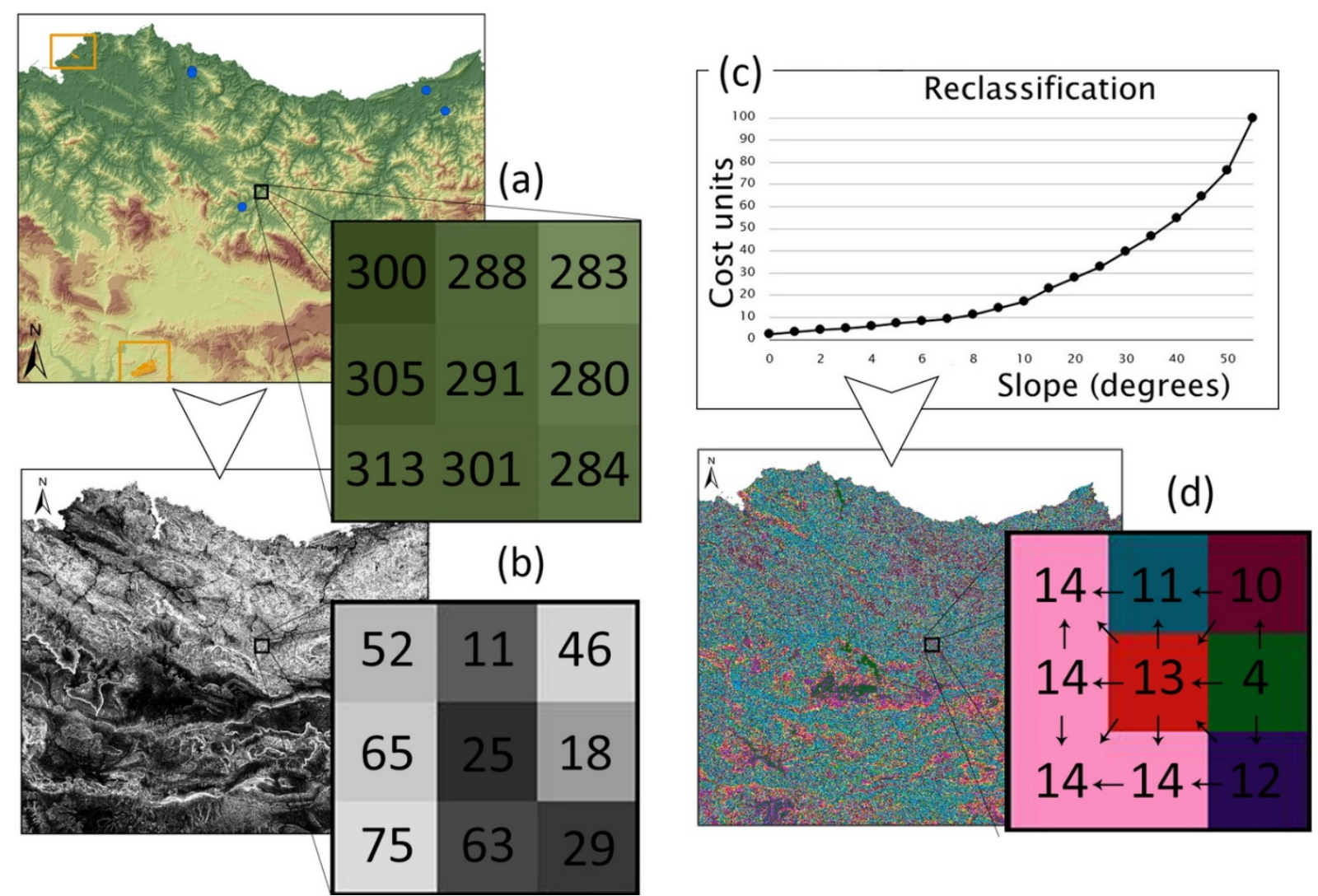

Figure 2. Methodological diagram showing the first four steps of the procedure for getting cost maps: a) digital elevation model showing the location of the archaeological sites and flint outcrops, with detail of the elevation value of each pixel; b) slope map, with detail of the slope value of each pixel; c) reclassification curve; d) slope map reclassified according to the reclassification curve.

The locations of the flint outcrops on the map were represented based on the geological units they belong to, as defined by the geological maps from the MAGNA 1:50.000 series provided by the Spanish Institute of Geology and Mining (IGME 2010c; a; b). In order to overcome the problem of identifying the precise location of the flint procurement places used by the Upper Palaeolithic societies, we decided to work with the centroid of the polygon drawn along the borders of each flint outcrop as a standardised procedure (Coordinates: Kurtzia Flysch UTM: 30T X:501638 Y:4803640; Treviño UTM: 30T X:518292 Y:4729046; Urbasa 30T X:570791 Y:4745451) (Figure 3.a). Once these points were located on the friction surface map (slope reclassified), we performed the geoprocess Cost distance tool (Figure 3.b). The resulting map shows, through a gradient of colours, the accumulated cost of carrying each variety of flint to any given point in the territory. Then we reclassified this map in ranges of 15,000 subunits (Figure 3.c). Each of these ranges was considered a Cost Unit (CU from now on). This step was performed in order to make representation and management of the data clearer and easier. (Figure 2.c). Finally, and with the aim of simplifying the visualization, we grouped the resulting values in groups of four CU by colour (Figure 3.c). 
Accessibility from the outcrops to each site is another research question to be considered in order to understand flint mobility networks. We used the same methodology to address it (Figure 4). We repeated the geoprocess Cost-distance tool, but in this case, obtaining two maps: an accumulated cost map originating from the outcrop under study (Figure 4.b), and a new one, the direction map (Figure 4.c). Combining both through the geoprocess Cost path tool, we obtained the optimal routes between the procurement areas and the sites: the paths of least accumulated cost between them and their length (Figure 4.d). In addition, we calculated the Euclidian distance between the centroids of the flint outcrops and the archaeological sites. All in all, we applied three different methodological approaches and, as a result, we obtained three different quantitative datasets to evaluate the same issue.

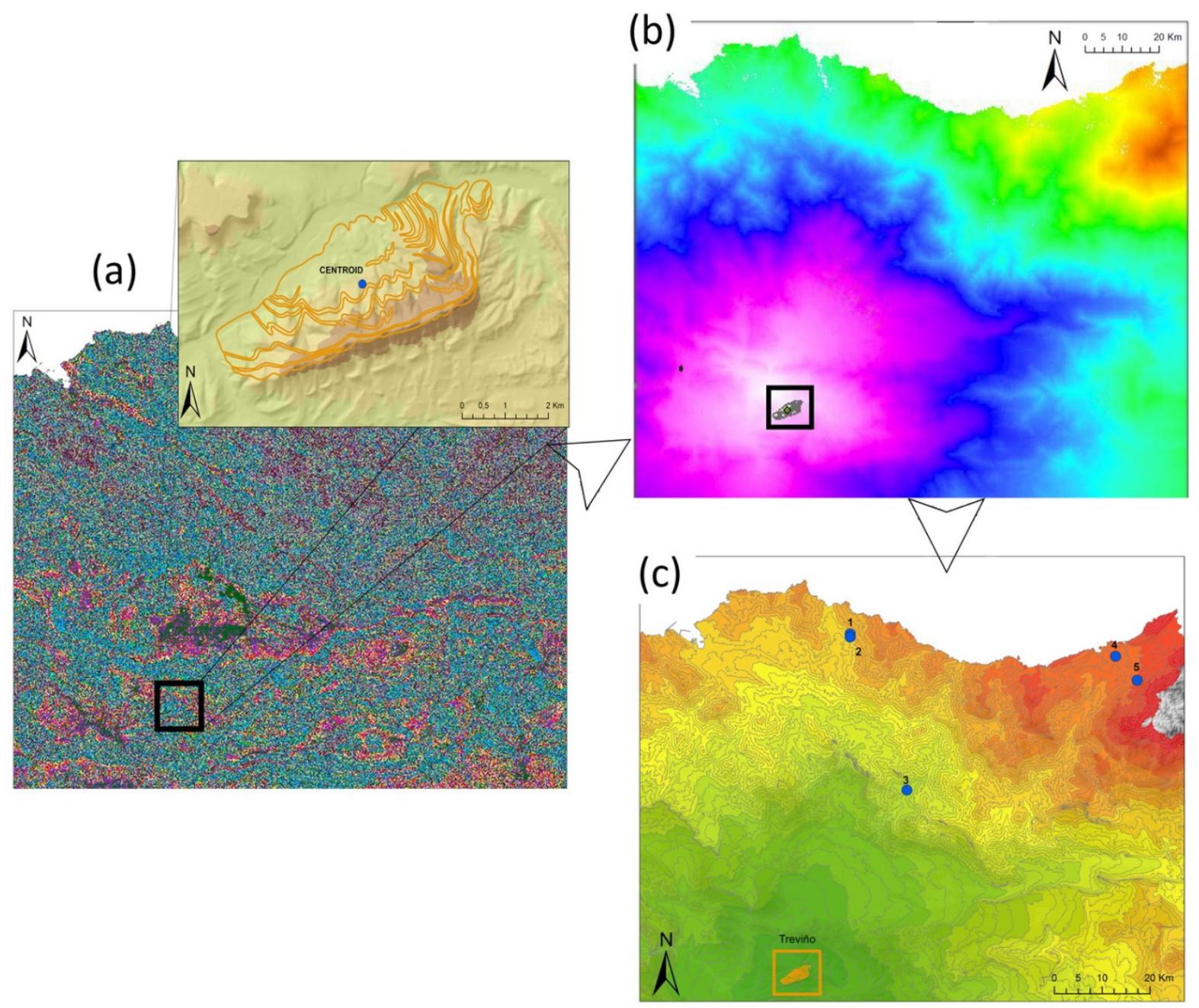

Figure 3. Methodological diagram showing the procedure for getting accumulated cost maps from a given outcrop: a) slope map reclassified according to the reclassification curve, with detail of the centroid of the outcrop of Treviño; b) accumulated cost map from the outcrop of Treviño; c) accumulated cost map from the outcrop of Treviño reclassified in CU. Scale bar in maps a to c is $20 \mathrm{~km}$, and is $2 \mathrm{~km}$ in the inset map.

Additionally, we used some statistical procedures to understand and observe the differences between these three datasets. The results were described and compared with the archaeological record -primarily the percentages of raw materials at each site and the clusters of points on biplot graphs.

Finally, and regarding the final goal stated, we would like to compare the different expansion ranges and the theoretical spread of the different flint varieties. To do so, we visually compared the expansion of each flint variety through two box plots. 


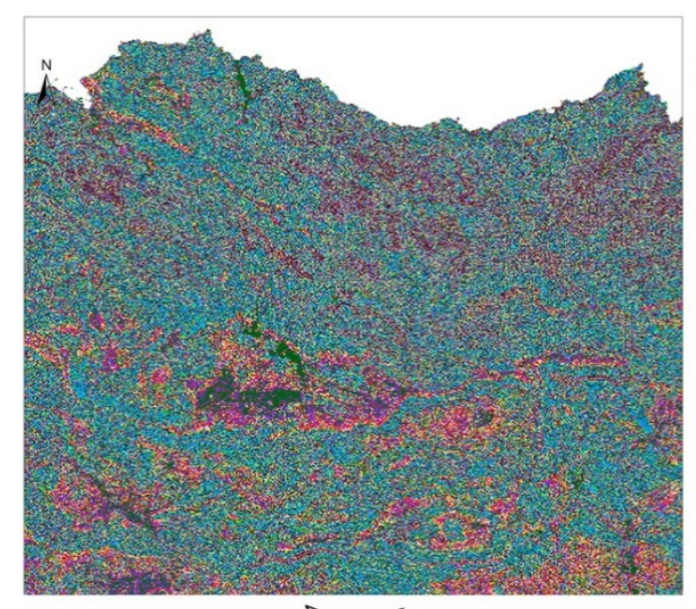

\section{(a)}
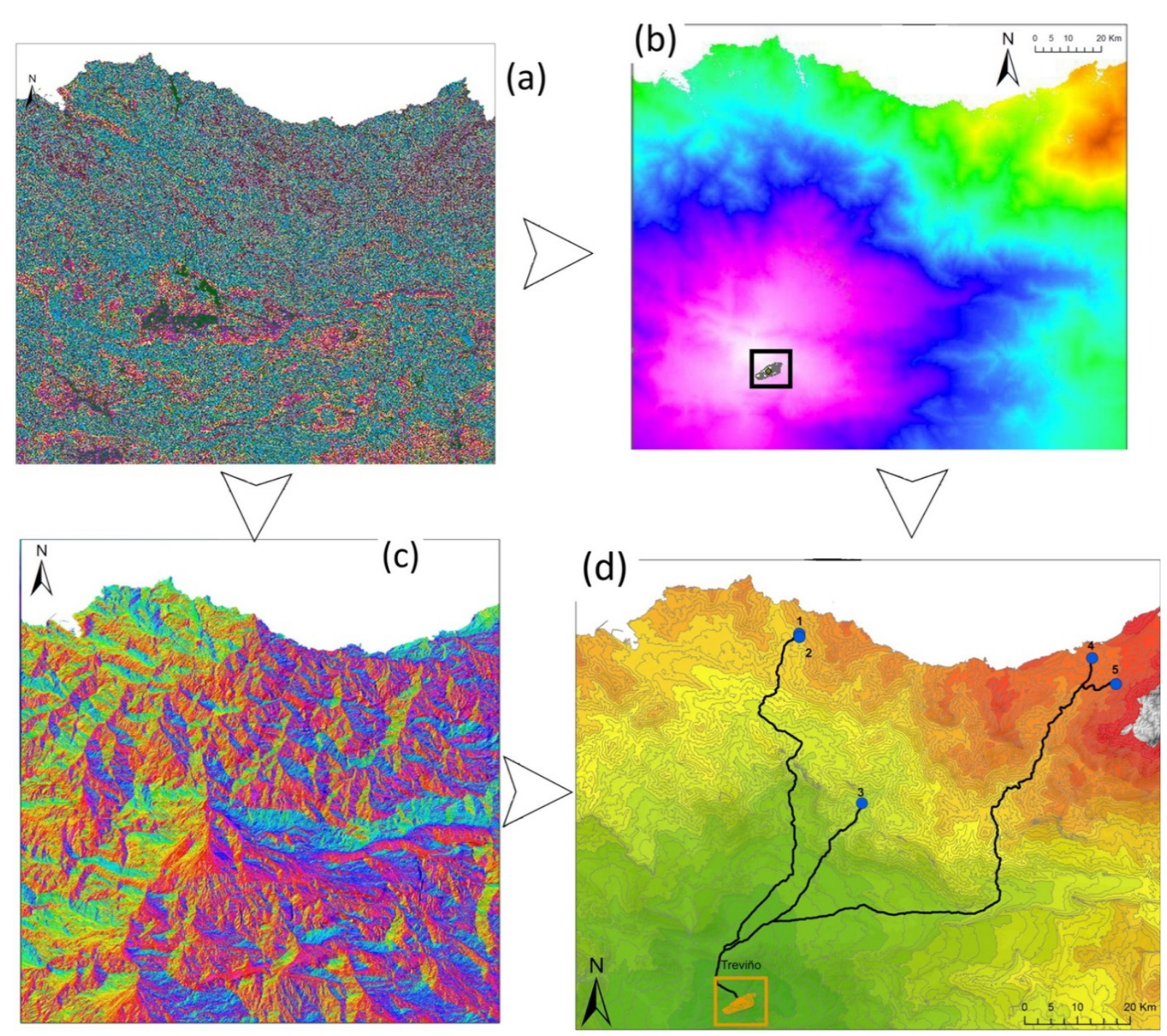

Figure 4. Methodological diagram showing the procedure for getting optimal routes and its comparison with CU and Euclidean distance: a) slope map reclassified according to the reclassification curve; b) accumulated cost map from the outcrop of Treviño; c) movement directionality map based on the cost map; d) map integrating CU and the linear magnitudes (Euclidean distance and optimal route).

\section{Results}

Traditionally the two approaches used to link flint outcrops and archaeological sites have been linear distance and distance through the optimal route. We also wanted to test these methodologies, so we produced three maps, one departing from each outcrop, with the objective of comparing these two traditional measurements with the one proposed in this paper: cost (Figure 5, 6 and 7). These figures represent the isocost lines from each of the three flint outcrops, showing the cost of a specific flint towards different sites and determining what the equivalent cost is. These maps also show the most relevant geographic units for human transit -such as plains, plateaus and valleys- represented by broad areas of the same colour. In addition, each map depicts, on the one hand, optimal routes, which show curvilinear shapes that adapt themselves to favourable passing zones, and, on the other, the Euclidean distances, which cross different geographic units regardless of their topography. 


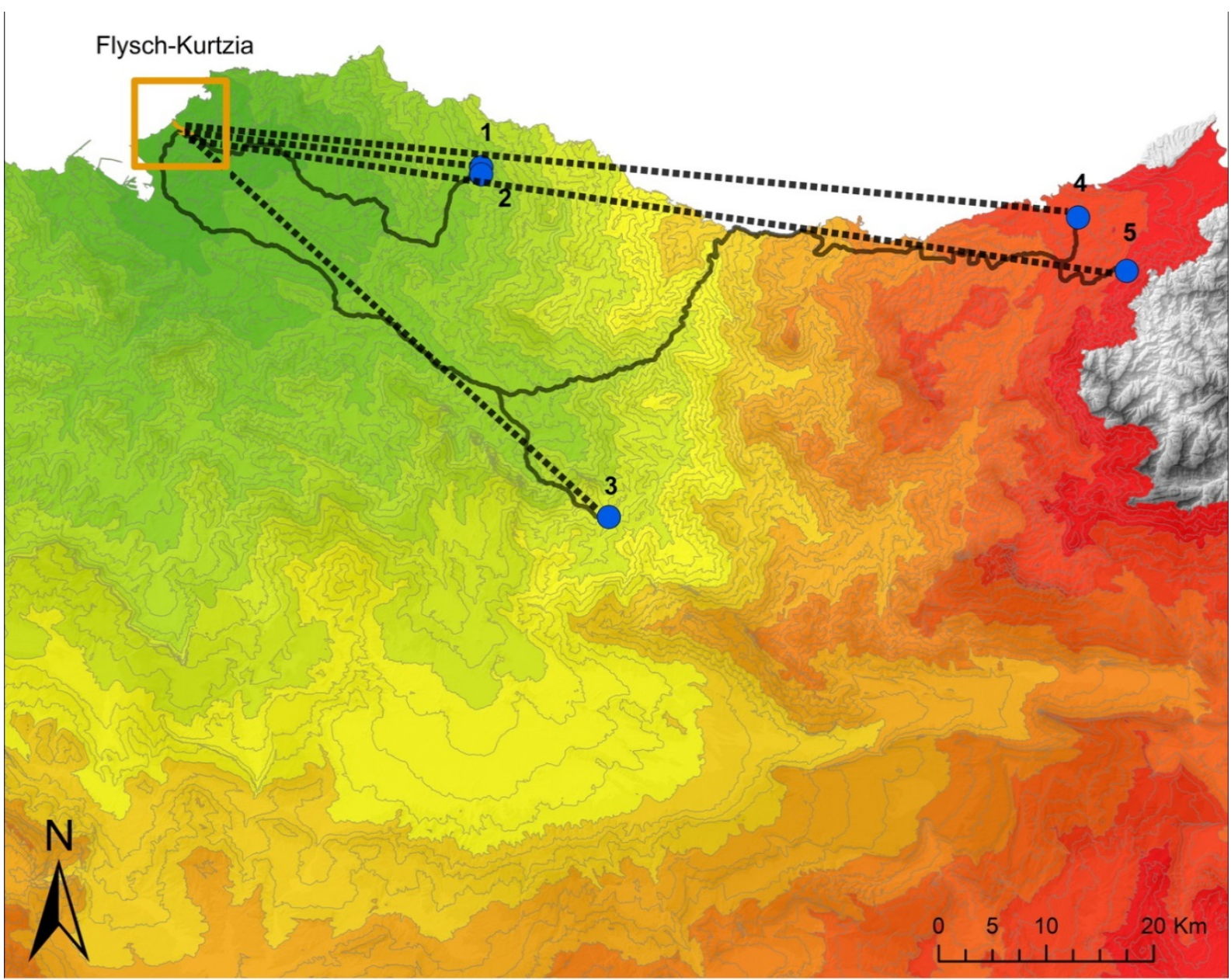

Cost Units:

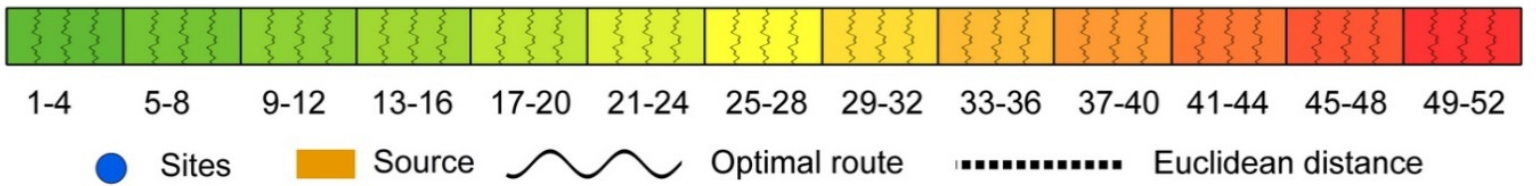

Figure 5. Map of the expansion of the Flysch Kurtzia flint representing the three types of measurement evaluated in this paper: Euclidean distance, the distance through the optimal route and cost. Legend: 1. Antoliñako Koba, 2. Santimamiñe, 3. Labeko Koba, 4. Ametzagaina and 5. Aitzbitarte III. 


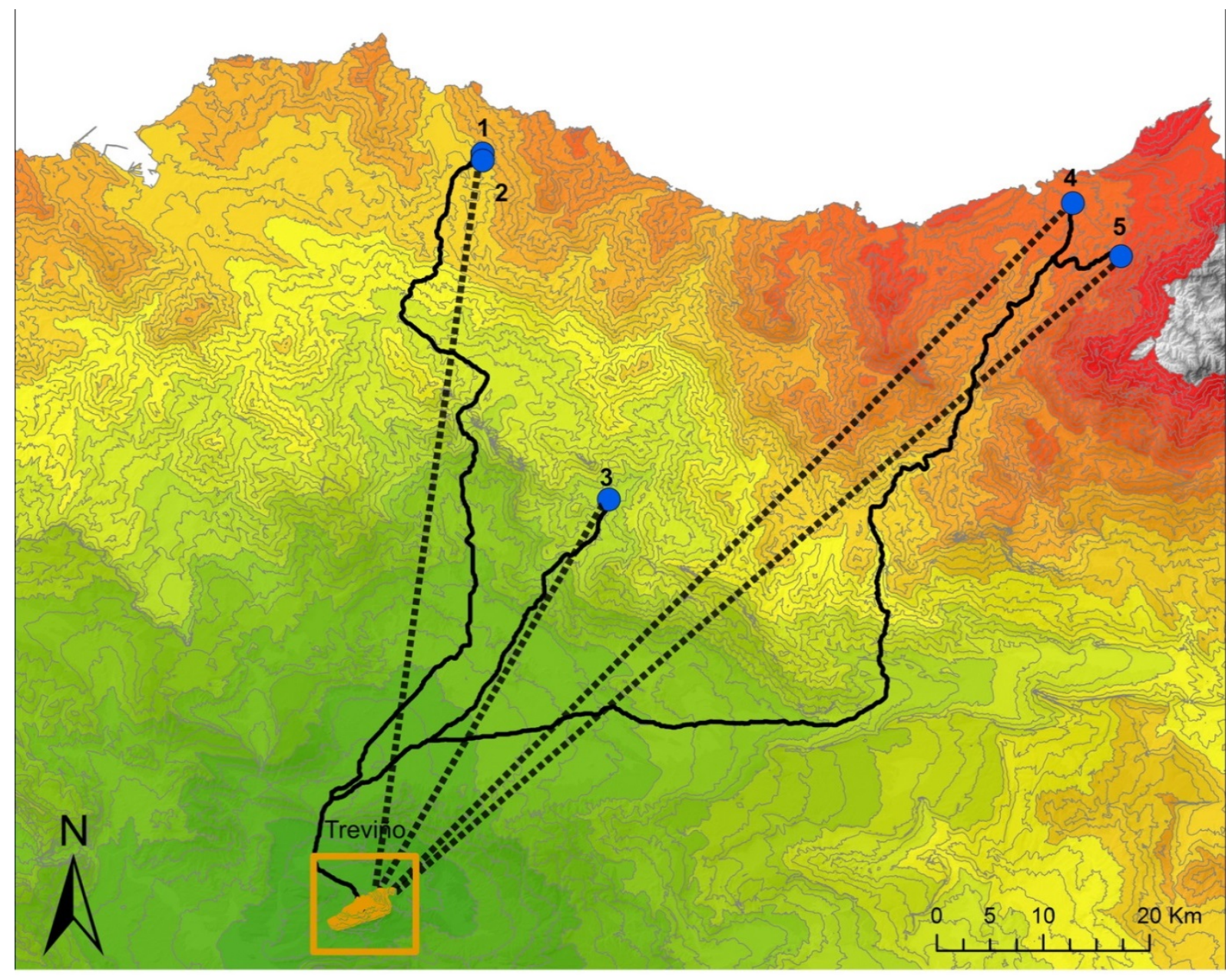

\section{Cost Units:}

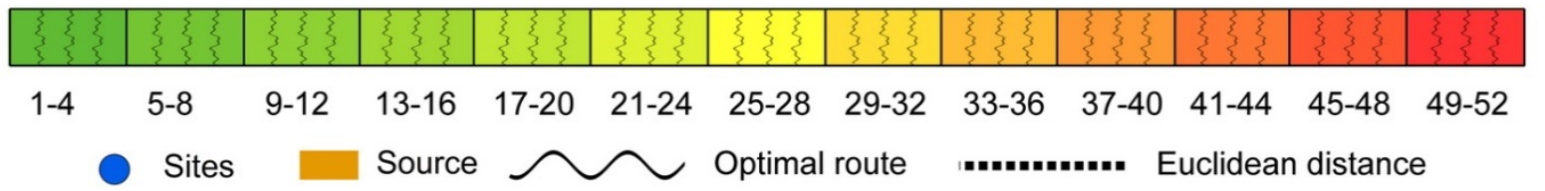

Figure 6. Map of the expansion of the Treviño flint representing the three types of measurement evaluated in this paper: Euclidean distance, the distance through the optimal route and cost. Legend: 1. Antoliñako Koba, 2. Santimamiñe, 3. Labeko Koba, 4. Ametzagaina and 5. Aitzbitarte III. 


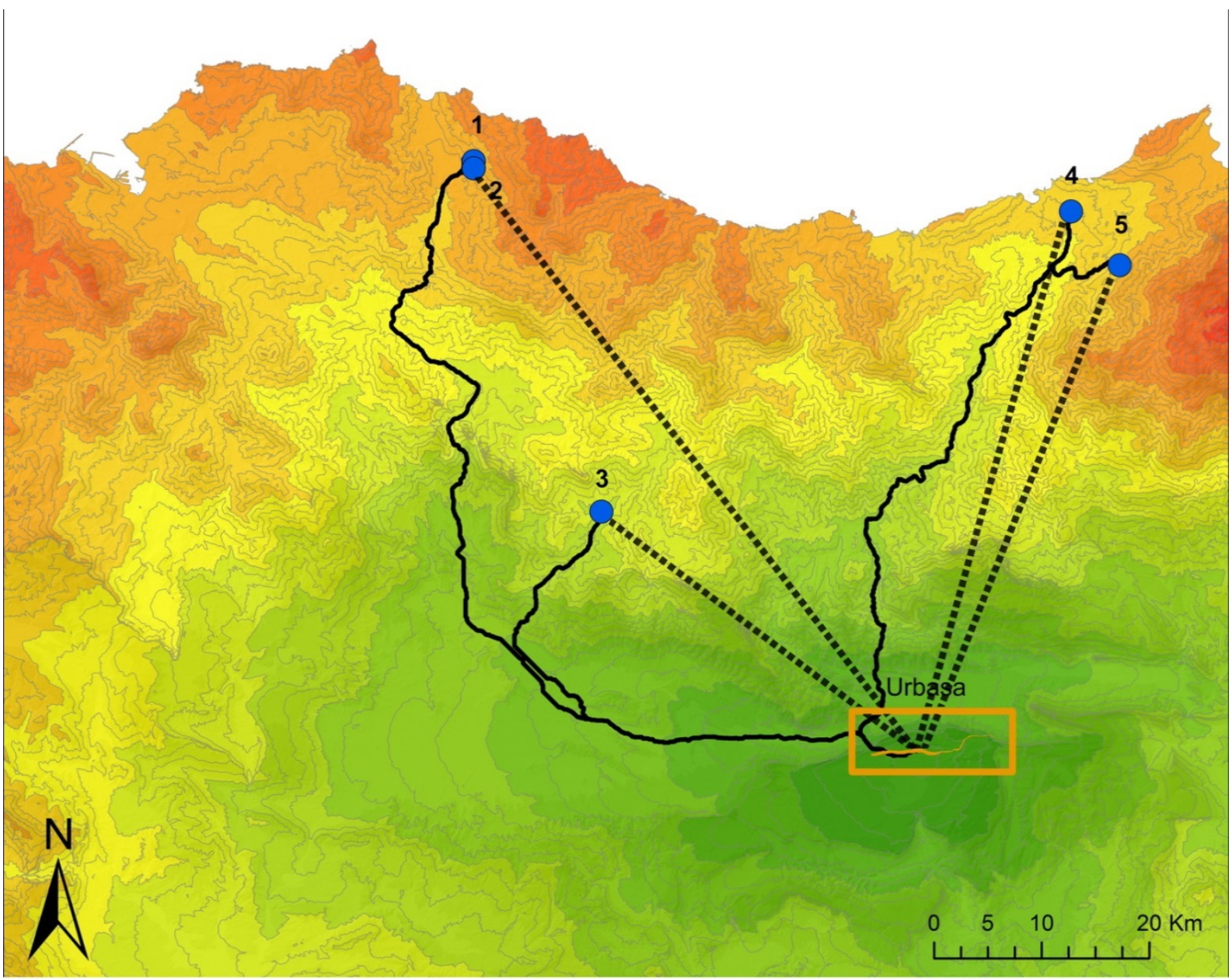

Cost Units:

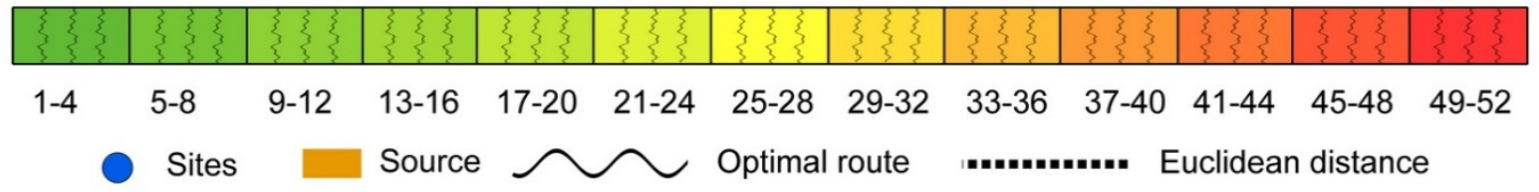

Figure 7. Map of the expansion of the Urbasa flint representing the three types of measurement evaluated in this paper: Euclidean distance, the distance through the optimal route and cost. Legend: 1. Antoliñako Koba, 2. Santimamiñe, 3. Labeko Koba, 4. Ametzagaina and 5. Aitzbitarte III. 
Using the data derived from this analysis, we put together a table that contains the Euclidean distance, the distance through the optimal route and the cost between each outcropsite combination (Table 2). The first two are expressed in metric units (kilometres) while cost is expressed in CU.

Table 2. Value of each possible site-outcrop route according to the three measurement methods proposed

\begin{tabular}{lccc}
\hline \multicolumn{1}{c}{ Routes } & $\begin{array}{c}\text { Euclidean distance } \\
(\mathbf{k m})\end{array}$ & $\begin{array}{c}\text { Optimal route } \\
\mathbf{( k m )}\end{array}$ & $\begin{array}{c}\text { Cost } \\
\text { (Cost units) }\end{array}$ \\
\hline Aitzbitarte III-Flysch Kurtzia (Ait-F) & 88.96 & 133.88 & 49 \\
\hline Aitzbitarte III-Treviño (Ait-T) & 94.22 & 137.73 & 44 \\
\hline Aitzbitarte III-Urbasa (Ait-U) & 49.05 & 75.43 & 31 \\
\hline Ametzagaina-Flysch Kurtzia (Ame-F) & 83.87 & 129.33 & 47 \\
\hline Ametzagaina-Treviño (Ame-T) & 94.32 & 134.78 & 42 \\
\hline Ametzagaina-Urbasa (Ame-U) & 52.08 & 72.5 & 29 \\
\hline Antoliñako Koba-Flysch Kurtzia (Ant-F) & 28.24 & 42.06 & 15 \\
\hline Antoliñako Koba-Treviño (Ant-T) & 72.27 & 96.7 & 32 \\
\hline Antoliñako Koba-Urbasa (Ant-U) & 68.77 & 106.98 & 35 \\
\hline Labeko Koba-Flysch Kurtzia (Lab-F) & 54 & 66.55 & 25 \\
\hline Labeko Koba-Treviño (Lab-T) & 45.12 & 56.65 & 21 \\
\hline Labeko Koba-Urbasa (Lab-U) & 36.9 & 61.42 & 23 \\
\hline Santimamiñe-Flysch Kurtzia (San-F) & 28.25 & 41.1 & 14 \\
\hline Santimamiñe-Treviño (San-T) & 71.52 & 95.63 & 32 \\
\hline Santimamiñe-Urbasa (San-U) & 68.11 & 105.9 & 35 \\
\hline
\end{tabular}

The resulting dataset is composed of 4 variables and 57 cases (one case for each route and archaeological level). All the variables are scales and they provide two different kinds of information: a) the percentage of flint from a specific flint outcrop identified at a specific archaeological site; and b) the measurements obtained through the three different methods that link flint outcrops with archaeological sites. We used statistical analysis in order to explore this dataset. The first step was to describe the data so as to select the most suitable test for the characteristics of our samples. The general description for the four variables is the following: Raw material distribution $(M=18.3, S D=25.03)$, Euclidean Distance $(M=61.64$; SD = 22), Optimal Route $(M=89,22$; SD = 33.35) and Cost Units $(M=31$; $S D=10.63)$. Kolmogorov-Smirnov test showed none of them follows normal distribution.

The second step was to represent this information using biplot charts (Figure 8), comparing the percentages of raw material distribution and the three different measurements obtained. The distribution of the plots seems to be guided by a linear regression, which is very similar in the three graphs. This line describes a clear inverse relation between the distance variables and the raw material percentages. That is to say, longer distance or higher CU are linked to a smaller quantity of the raw material under study in the corresponding archaeological levels, and vice versa. $\mathrm{R}^{2}$ is reported in each plot and shows good agreement with the regression line suggested for all cases. However, it also shows a ranking, with Cost Units being the measurement that better fits it. Spearman's Rho Coefficient presents a similar pattern and points out a stronger inverse dependence in the relationship Cost Unit measurement/Percentage of raw materials. The coefficients are the following: Euclidean distance $\rho(55)=-.802, \mathrm{P}<.001$; optimal route $\rho(55)=-.798, \mathrm{P}<.001 ; \mathrm{CU} \rho(55)=-.822, \mathrm{P}<$ .001. These statistical results demonstrate again a slightly better agreement between the archaeological percentages of raw materials and the data obtained from the Cost Units. 
Finally, in all three graphs the presence of three distinct groups can be noted: a first cluster, situated in the lower right area of the plot, a second cluster in the centre of the chart, and a third one in the upper left angle.
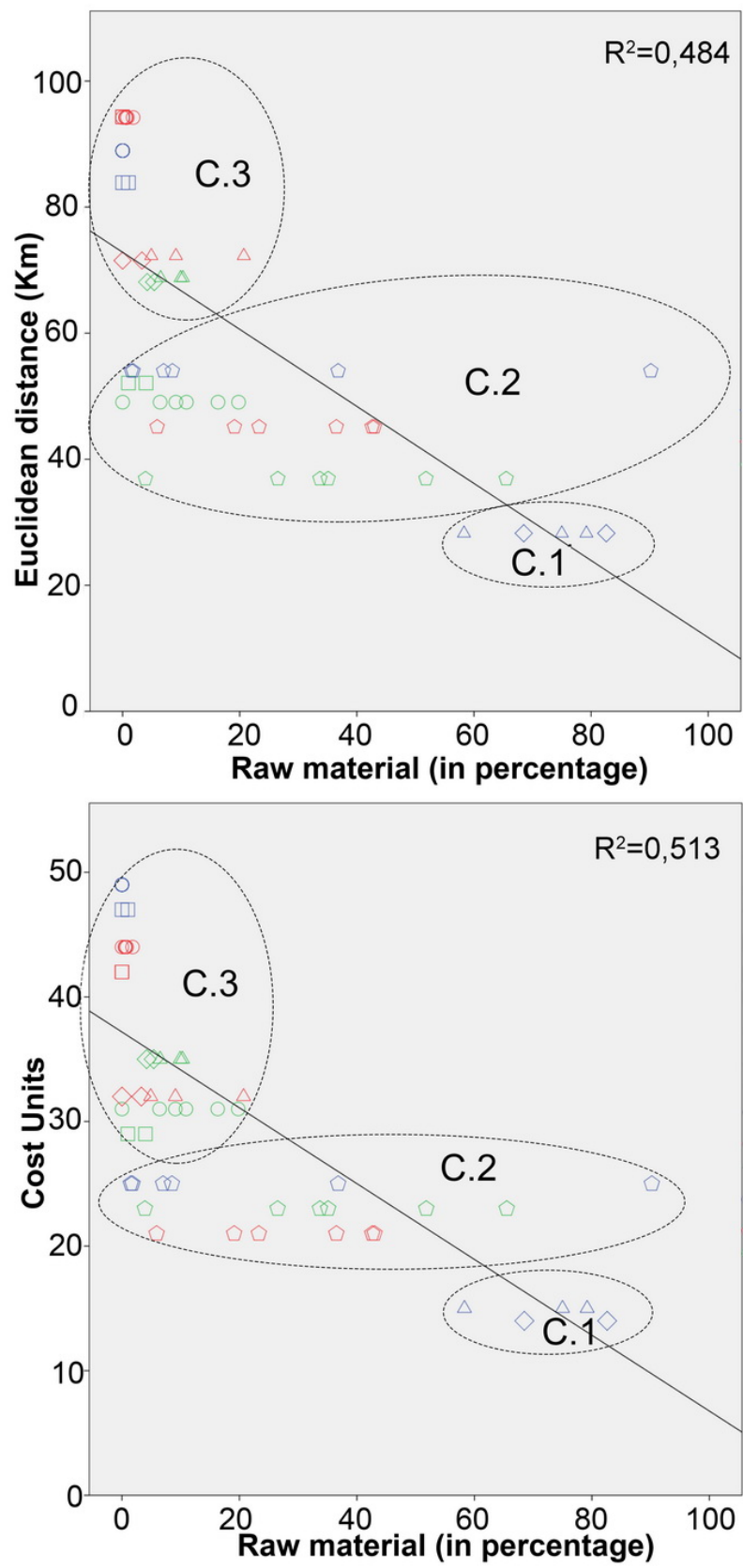

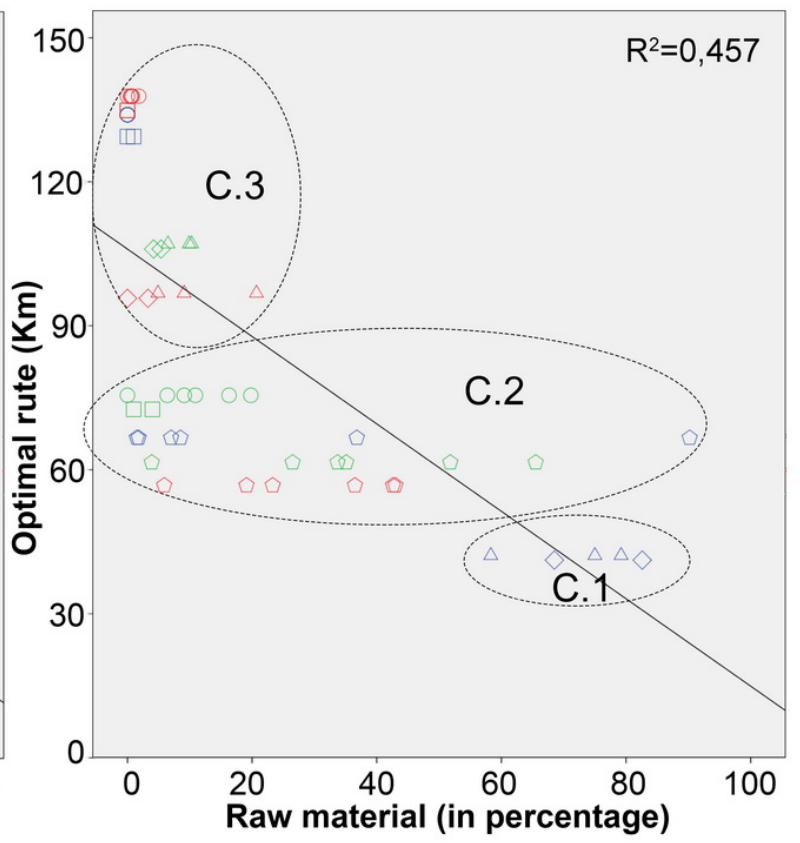

Routes

Aitzbitarte III-Flysch
Kurtzia
Aitzbitarte-Treviño
Aitzbitarte III-Urbasa
Ametzagaina-Flysch
Kurtzia
$\square$ Ametzagaina-Treviño
$\square$ Ametzagaina-Urbasa
$\triangle$ Antoliñako Koba-Flysch
Kurtzia
$\triangle$ Antoliñako Koba-Treviño
$\triangle$ Antoliñako Koba-Urbasa
Labeko Koba-Flysch
Kurtzia
Labeko Koba-Treviño
Labeko Koba-Urbasa
Santimamiñe-Flysch
Kurtzia
Santimamiñe-Treviño
Santimamiñe-Urbasa

Figure 8. Triple biplot chart with the three clusters proposed for each type of measurement. Each chart shows the percentage of raw material on the horizontal axis and the value of the measurement of each methodological proposal on the vertical axis. The two first are expressed in $\mathrm{Km}$ and the last one in Cost Units. It must be noted the points which compose each cluster are different depending on the measurement applied. Abbreviations: C.1 Cluster 1; C.2 - Cluster 2; C.3 - Cluster 3.

The next issue we faced was the detailed analysis of the relationship between raw material percentages and the data derived from the Cost Units measurements, in order to understand the different use of each flint outcrop. For this purpose, and excluding the archaeological levels with no presence of a specific raw material, we created a double boxplot to look at the different ranges of expansion from each outcrop more closely (Figure 9). This graph represents the differences in the expansion ranks from each outcrop and the percentage 
of flint carried to each of the archaeological sites. Urbasa and Treviño flints seem similar, but Kurtzia Flysch shows a different behaviour.
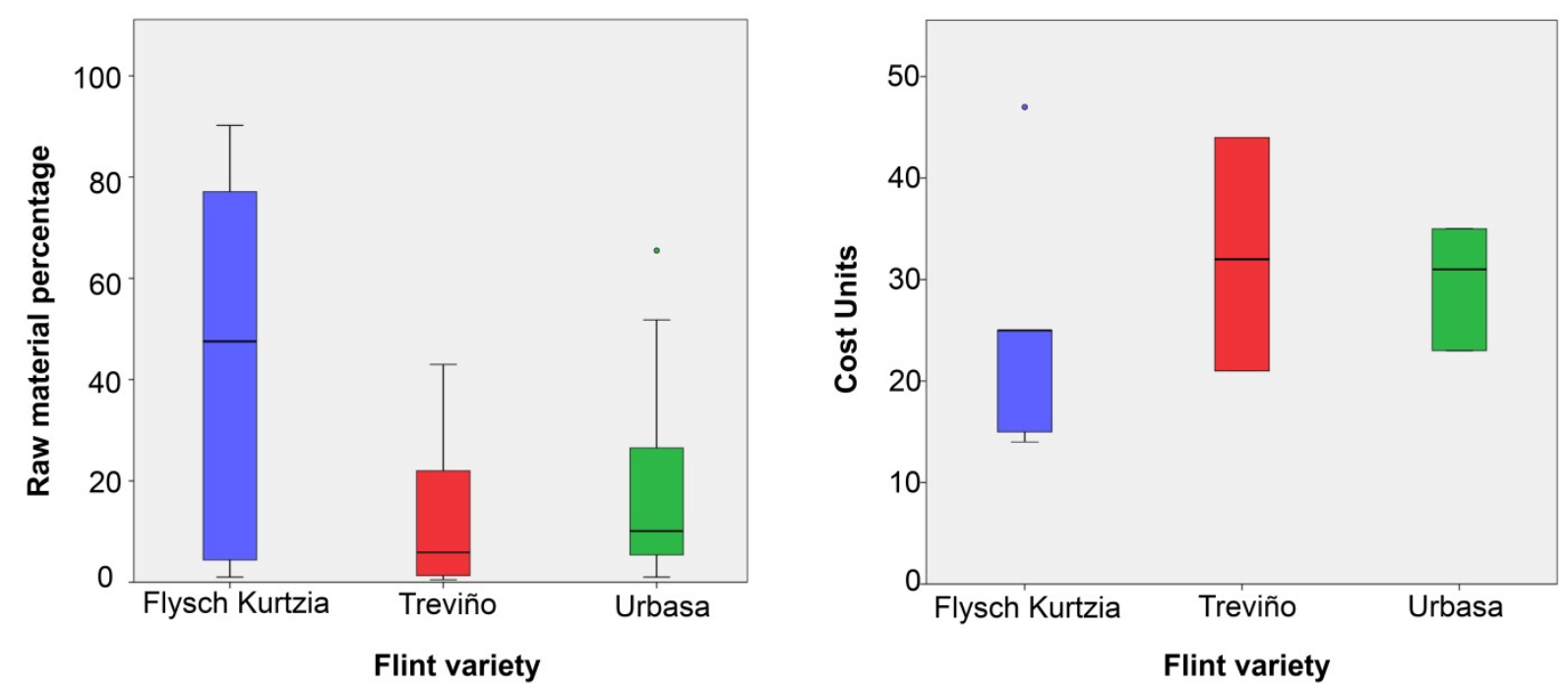

Figure 9. Double boxplot. The first plot shows the different varieties of flint on the horizontal axis and the Cost Units needed to reach each archaeological site with presence of that variety on the vertical axis. The second plot displays the percentage of flint from each outcrop identified in the all the archaeological sites under study.

\section{Discussion}

First, we would like to underline that this methodology is just a tool to model distance and orography and, therefore, to link this information to the archaeological record based on the percentages of raw material. Cost alone cannot explain the variability of the raw material distribution, but it is a good tool to make it visible and to start outlining some patterns. The raw material percentages in isolation cannot achieve this either; but, by combining both factors we can begin to understand raw material acquisition behaviour in this territory and overcome this long-lasting research bias. We are also aware of the existence of other socioeconomic and cultural factors that affect or determine hunter-gatherer mobility, which lead us to be cautious with our conclusions (e.g., Kelly 1992). Other physical constraints could also modify the results obtained here, but, as was already noted, we could not integrate them into this study due to the limited research/data available on them.

\subsection{Cost as an analysis and interpretation tool for lithic raw material procurement patterns}

For our purposes the concept cost can be defined as the energy spent by humans while traveling on rugged terrain (Surface-Evans and White 2012). The introduction of this idea diverges from previous studies on this topic, which only considered distance -Euclideanbetween sites and outcrops. The incorporation of topography is essential here, especially in mountainous areas and regions with highly variable altitudes, since it was a determining factor for moving back and forth across the landscape. All this leads us to introduce the new magnitude presented in the methodology: CU. Nevertheless, as we showed above, there is already extensive scientific literature that demonstrates the importance of LCA in order to understand the mobility of Palaeolithic groups.

As shown in the results, each approach tested gave us different interpretations of the distribution of the percentages of the raw materials from the different archaeological levels. Spearman's Rho Coefficient and $\mathrm{R}^{2}$ correlation show that the three methods of measurement point to the economic rule of cost, but each one points out slight differences. The biplot chart 
(Figure 8) makes these variations visible in the distribution of the points, which group into three clusters. The archaeological explanation for these groupings is determined by the theoretical approach stated above:

- The first cluster is comprised by the same points in all three charts. The correspondence of the cluster with the correlation line is clear and demonstrates the basic economic concept that a high quantity of raw material is associated with less effort. This cluster reflects the widespread idea derived from the archaeological literature of a direct and continuous exploitation of local lithic resources.

- The third cluster reflects the opposite idea: less quantity of raw material is associated with more effort to obtain it. This relationship shows a sporadic exploitation of the lithic resources within long-distance mobility. The points that make up this group are different in each plot since some of the points move between the second and third clusters depending on the measurement used.

- The second cluster is well distinguished from the others, but its archaeological interpretation is not clear. In the first (Euclidean distance) and second measurement methods (optimal route) the cluster is made up of all the archaeological levels from Labeko Koba, plus some from Aitzbitarte III and Ametzagaina. Instead, following the third approach (Cost Units) it turns out to be exclusively made up of Labeko Koba levels.

Focusing just on the last measurement (CU), the raw material distribution of the clusters derived from it shows high variability -among the analysed sites and within some of them(Figure 10). The CU needed to arrive at Labeko Koba from all three flint outcrops under study is similar. This means that raw material acquisition was based on a direct and continuous exploitation of a medium-to-long distance, variable over time. However, if we considered Euclidean distance or the optimal route, there would be no clear explanation since clusters 2 and 3 overlap. This demonstrates that these two traditional suggestions/explanations do not fit with the raw material distribution and the geographic constraints of the region.

To try to understand the origin of these differences, we graphically represented each of the 15 possible site-outcrop combinations analysed (Figure 11). Each figure shows one of the measurements in increasing order and compares it to the remaining two. It is clear that the sequence of the cases and the shape of the reference curve change greatly depending on the ordering criterion chosen. The first two cases are always the same, but after that, the sequence changes completely. These arguments demonstrate that linear distance and distance through the optimal route are not appropriate means to understand raw lithic material catchment by Palaeolithic groups. Considering this, in the following section we will analyse the relationship between the quantitative distribution of the different types of raw materials found at each site and the CU.

\subsection{Understanding variability in the movement and exploitation of flint during the Upper Palaeolithic in the south-western Pyrenees through Cost Units}

As was already mentioned, the Upper Palaeolithic of the western Pyrenees is an especially appropriate framework to illustrate the interest and value of this new methodological perspective. During this period, and particularly in the geographic area defined by the southern slope of the western Pyrenees, high mobility has already been observed. One of the main bodies of evidence is raw material procurement itself. From the beginning of the Upper Palaeolithic an intensive and systematic use of the three varieties of flint considered in this paper has been demonstrated (Tarriño 2006). On a broader scale, procurement frequently also included varieties located on the northern side of the Pyrenees (e.g., Tarriño 2011a; b; Arrizabalaga et al. 2014). Extraordinarily certain types, coming from up to 300 kilometres away, have been identified (Corchón et al. 2009). In general terms, 
throughout this period a northeast-southwest flint procurement axis crossing the Pyrenees predominated. Therefore, sites north of the Pyrenees have southern flint varieties in different percentages and vice versa (e.g., Tarriño \& Normand 2002). These long-distance contacts between both sides of the Pyrenean mountain range have also been noted for other material culture elements, such as for the bone industry, as exemplified by the Gravettian Isturitz-type bone points (Foucher \& San Juan-Foucher 2008). In addition, there is evidence of other longdistance contacts through different routes such as the one crossing the Ebro valley, as proven by a fragment of Spondylus sp. found in the Aurignacian level of Lezetxiki (Arrizabalaga et al. 2011).

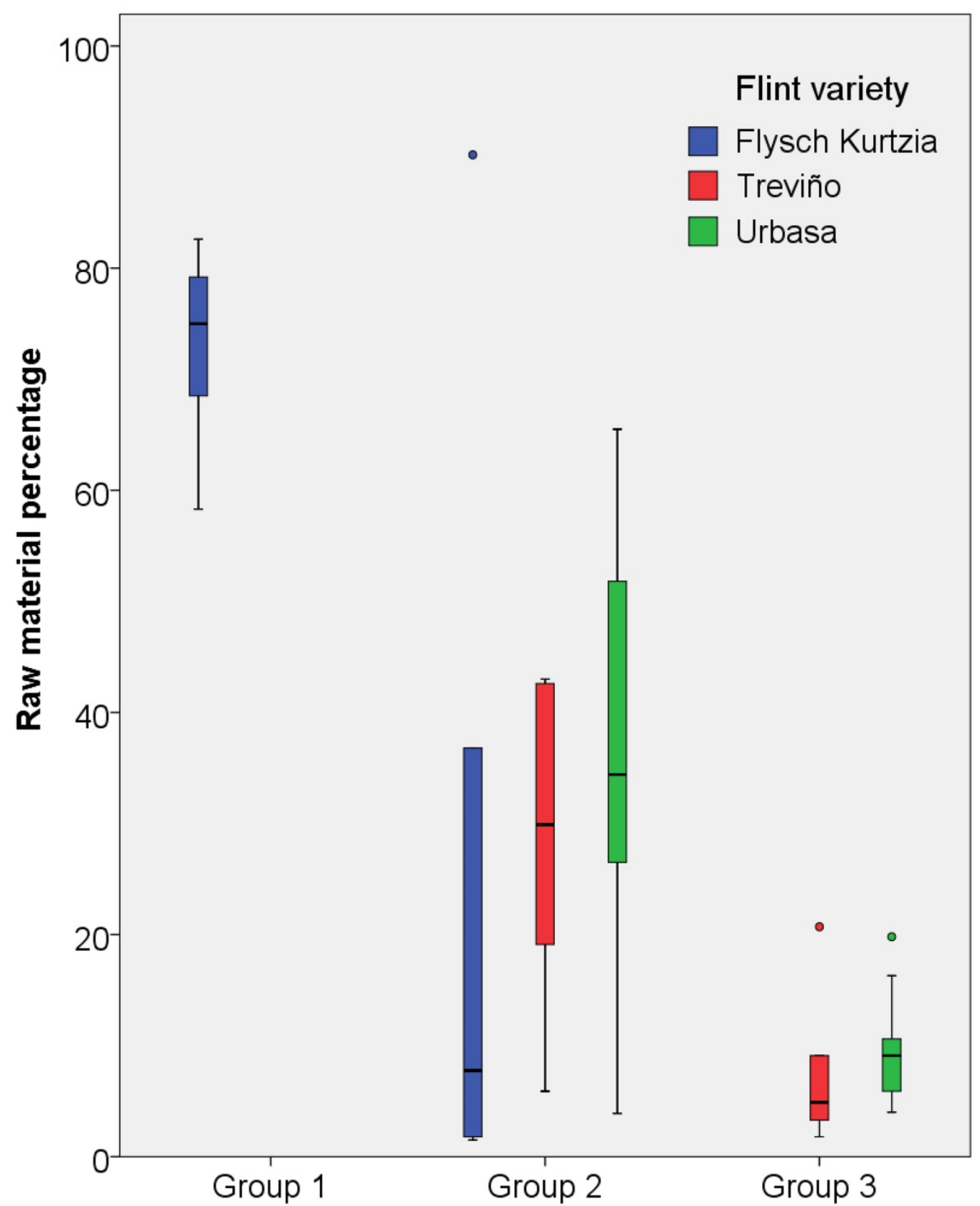

Figure 10. Boxplot which compares the variability of raw material percentages of each flint variety within each group proposed, using Cost Units.

We used the costs maps for each outcrop, where the dispersion of each type of flint is represented, to evaluate the relationship between distance and orography. In the case of the 
Kurtzia Flysch outcrop, the isocost lines are wider in a north-south direction (Figure 5). Instead, from Urbasa the lines follow both an east-west axis and a north-south one through the Oria basin (Figure 7). Meanwhile, the configuration of the isocost lines around the Treviño outcrop is more homogeneous, though slightly wider to the north-east (Figure 6).
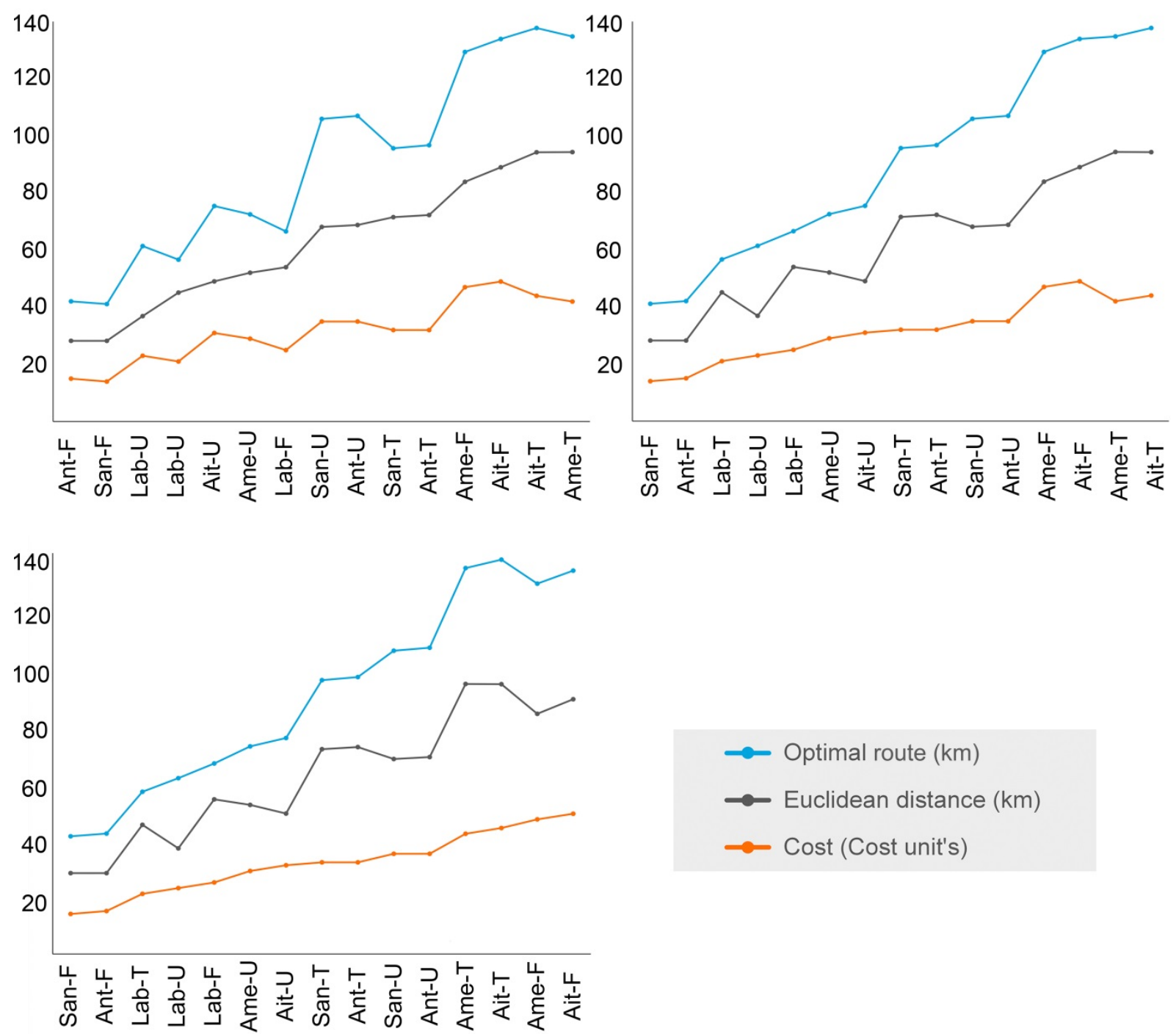

Figure 11. Triple graphic showing, on the horizontal axis, all the possible routes between archaeological sites and geological outcrops, ordered incrementally according to the three types of measurement used. The first one is ordered based on Euclidian distance, the second based on optimal route and the third is based on cost. The vertical axis represents two types of units of measurement contemporaneously on the same scale: kilometres, for Euclidian distance and optimal route, and CU, for cost. Variations in the order of the routes and the curves generated are observed.

Unequal behaviours for each outcrop can be noted when these are compared. The distribution area of Treviño is bigger than that of Kurtzia Flysch because it covers a broader area for the same cost. This is so because the density of the isocosts increases in the narrow coastal valleys due to the greater effort needed to cross them. Urbasa presents a wide spread, similar to that of Treviño. These conclusions are also supported by Figure 9, which represents the geographic spread of the different flint types. In this way, it is easy to identify the longtracer varieties: Urbasa and Treviño (Tarriño et al. 2015). Both flint types show extraordinary knapping properties and are widely distributed. Their overall percentages at the archaeological sites are low (except Labeko Koba), but they are nonetheless present in all of 
them. These two varieties seem to have slighter different areas of distribution: Urbasa flint has a higher presence in the eastern area and Treviño flint, on the contrary, in the western part. Nevertheless, both varieties first spread through the Alava plateau and later move to the north following the main fluvial valleys. Meanwhile, the outcrop of Kurtzia Flysch seems to have a restricted area of influence and a narrower distribution, clearly conditioned by the north-south mountainous ridges. The high percentages of this kind of flint at the archaeological sites in the western area of the Basque Country make this flint a low-medium scale tracer.

These reasonings lead us to establish three main types of flint procurement strategies by Upper Palaeolithic societies based on the cost of covering the routes between the outcrops and the sites. The first one is characterised by a primary and very frequent input of raw material from just one flint outcrop situated at less than $15 \mathrm{CU}$, showing a clear relation of autochthony. In the second case, the cost of the procurement routes is higher than $25 \mathrm{CU}$ and the proportion of raw material obtained is under $20 \%$. These types of flint are considered allochthonous and may reflect occasional catchment strategies inserted in territorial or longdistance mobility patterns (Binford 1982; 1983). These two types of flint procurement strategies overlap in most of the archaeological sites. Finally, the third type of catchment strategy is defined by routes between 21 and $25 \mathrm{CU}$. The raw material composition of this long-distance flint assemblages varies significantly between and inside the different archaeological sites. These changes are due to the similar cost involved to arrive at different outcrops and are linked to modifications in the mobility patterns or changes in the direct management of the territory. Within this type of procurement strategy, cost does not explain the changes in the preference for a specific flint variety.

Summing up, we consider that cost can be a powerful indicator to understand the distribution of different varieties of flint and to explain the configuration of the archaeological assemblages. It can also be a tool to approach the nature and evolution of accessibility to outcrops and, indirectly, to Upper Palaeolithic territoriality and mobility.

\section{Conclusions}

The main conclusions of the present study can be divided into two groups. At the methodological level, the use of GIS allowed us to consider topography as an important variable when measuring accessibility to lithic resources. In addition, thanks to the concepts cost and CU, we overcame the limitation imposed by linear distances in kilometres, whether through Euclidean distance or optimal routes. This is due to two reasons:

- Linear measurements (Euclidean distance or distance through an optimal route) do not consider topographic variations.

- Cost, and its measuring unit CU, is a magnitude applicable to any territory, not being exclusively determined by distance or a precise itinerary.

In terms of the results, this study interrelated accessibility to outcrops with the quantitative distribution of the different varieties of flint identified in the archaeological assemblages, thereby providing insights into the procurement strategies of raw materials of western Pyrenean Upper Palaeolithic groups. Thus, it was possible to identify patterns and strategies of territorial management, as well as to detect some of the variables behind them. The dichotomy of a primary and recurrent raw material acquisition below $15 \mathrm{CU}$ and a scarce or occasional catchment strategy over $25 \mathrm{CU}$ appeared clearly. Within the geographic area analysed, the differential spread of lithic resources was mainly conditioned by the accessibility to outcrops, even though in some cases this was not the most determining factor (e.g., Labeko Koba). Each flint variety showed different distribution patterns and CU let us identify the geographic opening and constraining areas. Although this relationship seemed 
clear, we must be cautious with our conclusions, because other types of socio-cultural and environmental factors not considered in this paper may have also played a major role in this equation.

The implementation of more precise and standardised protocols for the geological characterization of lithic assemblages could also improve and let us deepen into this line of research. Typological and technological studies, typometry or use-wear analyses could provide useful information too. In addition, the increase in the number of studies about on raw material characterisation from other archaeological sites could let us widen our framework, offering different perspectives on geographical and chronological variability. Finally, the combination of this approach with other sources, such as the catchment analysis of biological resources or the distribution of bone implements and mobile art, could offer us different perspectives and help us to better explain the mobility of Upper Palaeolithic groups.

\section{Acknowledgments}

This research was carried out with the financial support of the Government of the Basque Country (Research Group on Prehistory UPV/EHU IT622-13) and the Palmesopyr research network (CTP2012-R1). A.P., A.S., A.C. and E.D.B. are funded by the pre-doctoral programme of the Department of Education, Linguistics and Culture of the Government of the Basque Country (BFI-2012-121, BFI-2012-205, BFI-2011-101 and BFI-2010-333). M.G.R is funded by the Further Education programme for PhD researchers at the UPV/EHU. M.I.G.C. is funded by the FPU pre-doctoral programme of the Spanish Ministry of Education (AP2010-5177) and is a member of the Research Group on Heritage and Cultural Landscapes (IT315-10) financed by the Government of the Basque Country.

\section{References}

Aguirre, M. 2000, El yacimiento paleolítico de Antoliñako koba (Gautegiz-Arteaga, Bizkaia): secuencia estratigráfica y dinámica industrial. Avance de las campañas de excavación 1995-2000. Illunzar, 4: 39-81. (in Spanish) ("The Palaeolithic of Antoliñako koba (Gautegiz Arteaga, Bizkaia): stratigraphic sequence and industrial dynamics. An advance to 1995-2000 excavation seasons")

Aguirre, M. 2012, Ocupaciones gravetienses de Antoliñako koba: aproximación preliminar a su estratigrafía, cronología e industrias. In: Pensando el Gravetiense: Nuevos datos para la región cantábrica en su contexto peninsular y pirenáico (De las Heras, C., Lasheras, J.A., Arrizabalaga, A. \& de la Rasilla, M., Eds.) Monografías del Museo Nacional y Centro de Investigación de Altamira Vol. 23, Ministerio de Educación y Cultura., Madrid: p. 216-228. (in Spanish) ("Gravettian occupations of Antoliñako koba: preliminary approach to the stratigraphy, chronology and industries")

Altuna, J., Mariezkurrena, K. \& Ríos, J. 2011, Ocupaciones Humanas en Aitzbitarte III (País Vasco) 33.600-18.400 BP (Zona de entrada a la cueva). EKOB Euskal Kultura Ondare Bilduma Vol. 5, Eusko Jaurlaritzaren Argitalpen Zerbitzu Nagusia, Vitoria-Gasteiz, 536 p. (in Spanish) ("The human occupation of Aitzbitarte III (Basque Country) 33.60018.400 (Entrance of the cave area)")

Arias, P. 1992, Estrategias de aprovechamiento de las materias primas líticas en la costa oriental de Asturias (VIII-III milenios A.C.). In: Tecnología y Cadenas Operativas Líticas (Mora, R., Ed.) Treballs d'Arqueología Vol. 1, Universidad Autónoma de Barcelona, Barcelona: p. 37-56. (in Spanish) ("Lithic raw materials exploitation in the Western coastal area of Asturias (8th-3rd Millennia B.C.)") 
Arrizabalaga, A. 2007, Frontières naturelles, administratives et épistémologiques: L'unité d'analyse dans l'archéologie du Paléolithique (dans le cas basque). In: Frontières naturelles et frontières culturelles dans les Pyrénées préhistoriques (Cazals, N., González, J. \& Terradas, X., Eds.), PubliCan-Ediciones de la Universidad de Cantabria, Santander: p. 27-37. (in French) ("Natural, administrative and epistemological boundaries: The unit of analysis in Paleolithic archeology (in the Basque case)")

Arrizabalaga, A. 2009, The Middle to Upper Paleolithic Transition on the Basque Crossroads: Main Sites, Key Issues. Mitteilungen der Gesellschaft für Urgeschichte, 18: 39-70.

Arrizabalaga, A. \& Altuna, J., (Eds.) 2000, Labeko Koba (Arrasate, País Vasco): Hienas y humanos en los albores del Paleolítico superior. Munibe Vol. 52, Sociedad de ciencias Aranzadi, San Sebastián-Donostia, 395 p. (in Spanish) ("Labeko Koba (Arrasate, Basque Country): Hyenas and humans at the dawn of Upper Palaeolithic") URL: http://www.aranzadi.eus/fileadmin/docs/Munibe/2000001395AA.pdf

Arrizabalaga, A., Álvarez-Fernández, E. \& Iriarte-Chiapusso, M.J. 2011, Spondylus sp. at Lezetxiki cave (Basque Country, Spain): First evidence of its use in symbolic behaviour during Aurignacian in Europe. In: Spondylus in Prehistory: New data \& ApproachesContributions to the Archaeology of Shell Technologies (Ifantidis, F. \& Nikolaidou, M., Eds.), BAR International Series 2216, Archaeopress, Oxford: p. 11-16.

Arrizabalaga, A., Calvo, A., Elorrieta, I., Tapia, J. \& Tarriño, A. 2014, Where to and what for? Mobility patterns and the management of lithic resources by Gravettian huntergatherers in the Western Pyrenees. Journal of Anthropological Research, 70: 233-261. doi:10.3998/jar.0521004.0070.204

Arrizabalaga, A. \& Iriarte-Chiapusso, M.J. 2010a, El Gravetiense en la encrucijada. Actualización de la información y propuesta de relectura para el caso vasco. In: Cuaternario y Arqueología: Homenaje a Francisco Giles Pacheco (Mata Almonte, E., Ed.), Diputación Provincial de Cádiz, Servicio de Publicaciones: Asociación Profesional del Patrimonio, Cádiz: p. 133-146. (in Spanish) ("The Gravettian at the crossroad. Information update and rereading proposal for the Basque case")

Arrizabalaga, A. \& Iriarte-Chiapusso, M.J. 2010b, El Paleolítico superior inicial en el siglo XXI: Dos décadas de avances en la encrucijada vasca. In: El Paleolítico superior en la Península Ibérica: novedades del siglo XXI (Fullola, J.M., Mangado, J. \& Tejero, M., Eds.), SERP, Barcelona: p. 311-335. (in Spanish) ("The Early Upper Palaeolithic in the 21st century.Two decades of advances in the Basque crossroad")

Arrizabalaga, A., Iriarte-Chiapusso, M.J. \& Ordoño, J. 2013, Rivers, Mountains and Footpaths: the Basque Crossroads in the Framework of Palaeolithic Settlement in the Iberian Peninsula. In: Pleistocene foragers on the Iberian Peninsula: their culture and environment. Festschrift in honour of Gerd-Christian Weniger for his Sixtieth Birthday (Pastoors, A. \& Auffermann, B., Eds.), Wissenschaftliche Schriften des Neanderthal Museum, Mettmann: p. 25-34.

Aubry, T., Luís, L., Mangado, J. \& Matias, H. 2012, We will be known by the tracks we leave behind: Exotic lithic raw materials, mobility and social networking among the Côa Valley foragers (Portugal). Journal of Anthropological Science, 31: 528-550. doi:10.1016/j.jaa.2012.05.003 
Baceta, J.I. 1996, El Maastrichtiense superior, Paleoceno e Ilerdiense inferior de la Región Vasco-Cantábrica: secuencias deposicionales, facies y evolución paleogeográfica. Tesis Doctoral. Departamento de Estratigrafía y Paleontología, Universidad del País Vasco/Euskal Herriko Universitatea, Bilbao, 372 p. (in Spanish) ("Upper Maastrichtian, Paleocene and Lower Ilerdence from the Basque-Cantabrian Region: depositional sequences, facies and paleogeographical evolution")

de Barandiarán, J.M. 1976, Recapitulación y apéndice. In: Obras Completas (de Barandiarán, J.M., Ed.), Biblioteca de la Gran Enciclopedia Vasca Vol. 9 (Vasconia antigua: La cueva de Santimamiñe), Gran Enciclopedia Vasca, Bilbao: p. 421-475. (in Spanish) ("Summing-up and appendix. Complete works")

Bernabeu, J., Orozco, T. \& Terradas, X., (Eds) 1998, Los recursos abióticos en la Prehistoria. Caracterización, aprovisionamiento e intercambio, Collecció Oberta Vol. 2. Universitat de Valencia, Valencia, 188 p. (in Spanish) ("Abiotic resources in Prehistory. Characterization, catchment and interchange")

Binford, L.R. 1982, The archaeology of place. Journal of Anthropological Archaeology, 1(1): 5-31. doi:10.1016/0278-4165(82)90006-X

Binford, L.R. 1983, Long-term land use patterns: some implications for archaeology. In: Working at Archaeology (Binford, L.R., Ed.), Studies in Archaeology, Academic Press, New York: p. 379-386.

Binford, L.R. 2001, Constructing Frames of Reference. An Analytical Method for Archaeological Theory Building Using Hunter-gatherer and Environmental Data Sets. University of California Press, Berkeley, 563 p.

Bourguignon, L. \& Turq, A. 2008, Territoires lithologiques et axes de circulation au Paléolithique dans le nord-est aquitain. Archéopages, 21: p. 7-15. (in French) ("Lithological territories and directions of circulation in the Paleolithic in the Northeast of Aquitania")

Burke, A. 2004, Alternate Models of Spatial Organisation of Pleistocene Hunter-Gatherers. In: Hunters and Gatherers in Theory and Archaeology (Crothers, G.M., Ed.), Center for Archaeological Investigations, Southern Illinois University, Carbondale: p. 192-210.

Calvo, A. 2012, El yacimiento gravetiense al aire libre de Ametzagaina (Donostia, País Vasco). Los tecno-complejos líticos del Conjunto Oeste. CKQ: Estudios de Cuaternario/Kuaternario Ikasketak/Quaternary Studies, 2: 15-32. (in Spanish) ("The gravettian open air site of Ametzagaina (Donostia, Basque Country). The lithic technocomplexes of the Conjunto Oeste")

Calvo, A., Tapia, J., Arrizabalaga, A. \& Iriarte-Chiapusso, M.J. 2013, El yacimiento de Ametzagaina (Donostia, País Vasco). Un campamento gravetiense al aire libre en el Cantábrico. In: Pensando el Gravetiense: Nuevos datos para la región cantábrica en su contexto peninsular y pirenáico (De las Heras, C., Lasheras, J.A., Arrizabalaga, A. \& de la Rasilla, M., Eds.) Monografías del Museo Nacional y Centro de Investigación de Altamira Vol. 23, Ministerio de Educación y Cultura, Madrid: p. 229-241. (in Spanish) ("The archaeological site of Ametzagaina (Donostia, Basque Country). A Gravettian open air campsite in the Cantabrian region")

Close, A.E. 1996, Carry the weight: The use and transportation of stone tools. Current Anthropology, 37: 545-553. Stable URL: http://www.jstor.org/stable/2744555 
Connolly, J. \& Lake, M., (Eds) 2006, Geographical Information Systems in Archaeology, Cambridge Manuals in Archaeology. Cambridge University Press, Cambridge, 338 p.

Corchón, M.S., Martínez, J. \& Tarriño, A. 2009, Mobilité, territoires et relations culturelles au début du Magdalénien moyen cantabrique: nouvelles perspectives. In: Le concept de territoires dans le Paléolithique supérieur européen. Actes du XVe Congrès mondial (Lisbonne, 4-9 septembre 2006) (Djindjian, F., Kozlowski, J. \& Bicho, N., Eds.), BAR International Series Vol. 1938, Archaeopress, Oxford: p. 217-230. (in French)

("Mobility, territoriality and cultural relations at the beginning of the Cantabrian Middle Magdalenian: New perspectives")

Coward, F.S. 2004, Transitions, Change and Identity: the Middle and Upper Palaeolithic of Vasco-Cantabrian Spain. Ph.D. dissertation, University of Southampton, Southampton, $473 \mathrm{p}$.

Demars, P.Y. 1982, L'utilisation du silex au Paléolithique supérieur: choix, approvisionnement, circulation. L'exemple du bassin de Brive. Cahiers du Quaternaire Vol. 5, CNRS, París, 253 p. (in French) ("The use of flint in the Upper Palaeolithic: Selection, catchment and circulation. The example of Brive valley")

Djindjian, F. 2009, Le concept de territoires pour les chasseurs cueilleurs du Paléolithique supérieur européen. In: Le concept de territoires dans le Paléolithique supérieur européen. Actes du XVe Congrès mondial (Lisbonne, 4-9 septembre 2006) (Djindjian, F., Kozlowski, J. \& Bicho, N., Eds.), BAR International Series Vol. 1938, Archaeopress, Oxford: p. 3-25. (in French) ("The concept of territories for the huntergatherers societies in European Upper Palaeolithic")

Djindjian, F., Kozlowski, J. \& Otte, M. 1999, Le Paléolithique supérieur en Europe. Armand Colin, Paris, 474 p. (in French) ("The Upper Palaeolithic in Europe")

Fábrega, P. \& Parcero, C. 2007, Proposals for an archaeological analysis of pathways and movement. Archeologia e Calcolatori, 18: 121-140.

URL: http://soi.cnr.it/archcalc/indice/PDF18/7_Fabrega.pdf

Fairén, S. 2004, ¿¿Se hace camino al andar? Influencia de las variables medioambientales y culturales en el cálculo de caminos óptimos mediante SIG. Trabajos de Prehistoria, 61(2): 25-40. (in Spanish) ("Is there any way out there? Environmental and cultural influences in computing Least-Cost Path with GIS"). doi:10.3989/tp.2004.v61.i2.41

Fernández, J.F. 2010, Una aportación desde la arqueología del paisaje al conocimiento del primer poblamiento humano del Valle del Trubia. Estudio geoarqueológico y análisis SIG del territorio. Ediciones de la Universidad de Oviedo, Oviedo, 198 p. (in Spanish) ("The first human settlement in the Trubia valley through landscape archaeology approach. Geoarchaeology and GIS analyses")

Foucher, P. \& San Juan-Foucher, C. 2008, Du silex, de l'os et des coquillages : matières et espaces géographiques dans le Gravettien pyrénéen. In: Space and Time: Which Diachronies, Which Synchronies, Which Scales? / Typology vs. Technology. Actes du XVe Congrès Mondial de l'Union Internationale des Sciences Préhistoriques et Protohistoriques (UISPP) de Lisbonne (Aubry, T., Almeida, F., Araújo, A.C. \& Tiffagom, M., Eds.), BAR International Series 1831, Archaeopress, Oxford, England: p. 45-55. (in French) ("Of flint, bone and shells: Materials and geographical areas in the Pyrenean Gravettien") 
García, A. 2010, Patrones de asentamiento y ocupación del territorio en el Cantábrico Oriental al final del Pleistoceno. Una aproximación mediante SIG. Doctoral Thesis. Departamento de Ciencias Históricas, Universidad de Cantabria, Santander, 395 p. (in Spanish) ("Settlement and occupation pattern in Eastern Cantabrian region at the end of the Pleistocene. An approach through GIS") URI: http://hdl.handle.net/10902/2315

Geneste, J.M., Castel, J.C. \& Chadelle, J.P. 2008, From physical to social landscapes: multidimensional approaches to the archaeology of social place in the European Upper Palaeolithic. In: Handbook of Landscape Archaeology (David, B. \& Thomas, J., Eds.), Left Coast Press Inc., Walnut Creek, California: p. 228-236.

Geneste, J.M. \& Rigaud, J.P. 1977, Matières premières lithiques et occupation de l'espace. In: Approche écologique de l'homme fossile (Laville, H. \& Renault-Miskovsky, J., Eds.) Supplement au Bulletin AFEQ Vol. 47, Universite Pierre et Marie Curie, Paris: p. 205218. (in French) ("Lithic raw materials and use of space")

Grove, M. 2009, Hunter-gatherer movement patterns: Causes and constraints. Journal of Anthropological Archaeology, 28: 222-233. doi:10.1016/j.jaa.2009.01.003

Güimil-Fariña, A. \& Parcero-Oubiña, C. 2015, “Dotting the joins”: a non-reconstructive use of Least Cost Paths to approach ancient roads. The case of the Roman roads in the NW Iberian Peninsula. Journal of Archaeological Science, 54: 31-44. doi:10.1016/j.jas.2014.11.030

Hamilton, M.J., Milne, B.T., Walker, R.S., Burger, O. \& Brown, J.H. 2007, The complex structure of hunter-gatherer social networks. Proceedings of the Royal Society B: Biological Sciences, 274: 2195-2203. doi:10.1098/rspb.2007.0564

IGME 2010a, MAGNA $2^{a}$ Ed., Algorta 37-4. Instituto Geológico y Minero de España, Madrid. (in Spanish) ("MAGNA (Geological map of Spain) 2nd, Algorta”)

IGME 2010b, MAGNA $2^{a}$ Ed., Altsasu 114-3. Institito Geológico y Minero de España, Madrid. (in Spanish) ("MAGNA (Geological map of Spain) 2nd , Altsasu”)

IGME 2010c, MAGNA $2^{a}$ Ed., Treviño 138-3. Instituto Geográfico Minero de España, Madrid. (in Spanish) (“MAGNA (Geological map of Spain) 2nd, Treviño”)

IGN 2014, Centro de Descargas del Instituto Geográfico Nacional Español. (in Spanish) ("Download Center from the National Geographical Institute of Spain”) Retrieved: 18 December 2014. URL: http://centrodedescargas.cnig.es/CentroDescargas/

Kantner, J. 2012, Realism, Reality and Routes. Evaluating Cost-Surface and Cost-Path Algorithms. In: Least Cost Analysis of Social Landscapes: Archaeological Case Studies (White, D. \& Surface-Evans, S., Eds.), The University of Utah Press, Salt Lake City: p. 225-238.

Kelly, R.L. 1992, Mobility/Sedentism: Concepts, Archaeological Measures, and Effects. Annual Review of Anthropology, 21: 43-66. doi:10.2307/2155980

Kelly, R.L. 1995, The foraging spectrum. Diversity in hunter-gatherer lifeways. Percheron Press, New York, $446 \mathrm{p}$.

Kramer, P.A. 2010, The Effect on Energy Expenditure of Walking. American Journal of Human Biology, 22: 497-507. doi:10.1002/ajhb.21027

Langmuir, E. 1984, Mountaincraft and Leadership. Scottish Sports Council, Glasgow, 361 p. 
López Quintana, J.C., (Ed), 2011, La cueva de Santimamiñe revisión y actualización (20042006), Kobie-Excavaciones Arqueológicas en Bizkaia Vol. 1, Diputación Foral de Bizkaia, Bilbao, 446 p. (in Spanish) ("Santimamiñe cave: Revision and update (20042006)")

López Romero, R. 2005, Cálculo de rutas óptimas mediante SIG en el territorio de la ciudad celtibérica de Segeda. Propuesta metodológica. SALDVIE, 5: 95-111. (in Spanish) ("Calculation of optimal path in the territory of the celtiberic city of Segeda. Methodological proposal")

Llobera, M. 2000, Understanding movement: a pilot model towards the sociology of movement. In: Beyond the Map. Archaeology and Spatial Technologies (Lock, G., Ed.), IOS Press, Amsterdam: p. 65-83.

Llobera, M., Fábrega-Álvarez, P. \& Parcero-Oubiña, C. 2011, Order in Movement: a GIS approach to accessibility. Journal of Archaeological Science, 38: 843-851. doi:10.1016/j.jas.2010.11.006

Mangado, J. 2006, El aprovechamiento en las materias primas líticas: Hacia una caracterización paleocultural de los comportamientos paleoeconómicos. Trabajos de Prehistoria, 63(2): 79-91. (in Spanish) ("The procurement of lithic raw materials: Towards a paleocultural characterization of paleoconomic behaviour"). doi:10.3989/tp.2006.v63.i2.18

Marín, A.B. 2008, Patrones de movilidad y control del territorio en el Cantábrico Oriental durante el Tardiglaciar. Trabajos de Prehistoria, 65: 29-45. (in Spanish) ("Mobility patterns and control of the Eastern Cantabrian territory during Late Last Glacial"). doi:10.3989/tp.2008.v65.i1.134

Marín, A.B. 2009, The Use of Optimal Foraging Theory to Estimate Late Glacial Site Catchment Areas from a Central Place: The Case of Eastern Cantabria. Journal of Anthropological Archaeology, 28(1): 27-36. doi:10.1016/j.jaa.2008.11.001

Mathey, B. 1982, El Cretácico Superior del Arco Vasco. In: El Cretácico de España, Universidad Complutense de Madrid, Madrid: 111-135 p. (in Spanish) ("Upper Cretaceous in the Basque Region")

Minnetti, A.E. 1995, Optimum Gradient of Mountain Paths. Journal of Applied Physiology, 79(5): 1698-1703. URL: http://jap.physiology.org/content/79/5/1698.article-info

Murrieta-Flores, P.A. 2010, Travelling in a Prehistoric Landscape: Exploring the Influences that Shaped Human Movement. In: Making History Interactive. Computer Applications and Quantitative Methods in Archaeology (CAA), Proceedings of the 37th International Conference, Williamsburg, Virginia, United States of America, March 22-26, 2009 (Frischer, B., Webb Crawford, J. \& Koller, D., Eds.), BAR International Series 2079, Archaeopress, Oxford: p. 258-276.

Murrieta-Flores, P.A., Wheatley, D. \& García Sanjuán, L. 2009, Movilidad y vías de paso en los paisajes prehistóricos: megalitos y vías pecuarias en Almadén de la plata. In: Tecnologías de información geográfica y análisis arqueológico del territorio. Actas del V Simposio Internacional de Arqueología de Mérida (Mayoral Herrera, V. \& Celestino Pérez, S., Eds.), Instituto de Arqueología-Mérida. CSIC-Junta de ExtremaduraConsorcio de Mérda, Mérida: p. 1-16. (in Spanish) ("Mobility and routes in prehistoric landscapes: megalithic and cattle path in Alamaden de la Plata (Sevilla, Spain)") 
Pandolf, K.B., Burse, R.L. \& Goldman, R.F. 1977, Role of Physical Fitness in Heat Acclimatization, Decay and Reinduction. Ergonomics, 20: 399-408. doi:10.1080/00140137708931642

Parcero, C., Fábrega, P., Güimil, A., Fonte, J. \& Valdez, J. 2009, Castros, caminos, rutas y ocupación del espacio. Modelización y análisis de las formas de movilidad asociadas a los asentamientos de la Edad del Hierro a través de herramientas SIG. In: Arte rupestre, paleoambiente y paisaje. Miradas interdisciplinares sobre Campo Lameiro (Criado, F. \& Martínez Cortizas, A., Eds.), TAPA, CSIC, Santiago: p. 171-186. (in Spanish) ("Fortification, paths, routes and settlement in the space. Modelization and analysis of the mobility associated to Iron Age settlement through GIS")

Rissetto, J.D. 2009, Late Pleistocene Hunter-Gatherer mobility patterns and lithic exploitation in Eastern Cantabria (Spain). Ph.D. Dissertation. Department of Anthropology, University of New Mexico, Albuquerque, 336 p.

Rissetto, J.D. 2012, Using Least Cost Path Analysis to Reinterpret Late Upper Paleolithic Hunter-Gatherer Procurement Zones in Northern Spain. In: Least Cost Analysys of Social Landscapes. Archaeological Case Studies (White, D.A. \& Surface-Evans, S.L., Eds.), University of Utah Press, Salt Lake City: p. 11-31.

Sarabia Rogina, P. M., 1995. Las estrategias de aprovisionamiento de materias primas líticas en la transición del paleolítico medio-superior en Cantabria. In: Actas del XXII Congreso Nacional de Arqueología: Vigo 1993 Vol. 1, Xunta de Galicia, Santiago de Compostela: p. 357-366.

Simonnet, R. 1996, Approvisionnement en silex au Paléolithique supérieur: déplacements et caractéristiques physionomiques des paysages, l'exemple des Pyrénées Centrales. In: Pyrénées Préhistoriques. Arts et Sociétés, actes du 118e congrès national des sociétés historiques et scientifiques, Pau 1993 (Delporte, H. \& Clottes, J., Eds.), Editions du CTHS, Paris: p. 117-128. (in French) ("Flint procurement in the Upper Palaeolithic: movements and physionomic characterization of the landscape, the example of Central Pyrenees")

Surface-Evans, S. L. \& White, D.A., An Introduction to the Least Cost Analysis of Social Landscape. In: Least Cost Analysys of Social Landscapes. Archaeological Case Studies (White, D.A. \& Surface-Evans, S.L., Eds.), University of Utah Press, Salt Lake City: p. 1-7.

Tapia, J., Arrizabalaga, A., Iriarte-Chiapusso, M.J. \& Calvo, A. 2009, El campamento gravetiense de Ametzagaina (Donostia, País Vasco). Un avance a su estudio arqueológico. Munibe, 60: 99-115. (in Spanish) ("The Gravettian camp-site of Ametzagaina (San Sebastián, Spain). A first analysis on the site") URL: http://www.aranzadi.eus/fileadmin/docs/Munibe/2009099115AA.pdf

Tarriño, A. 2000, Estudio de la procedencia de los sílex recuperados en el yacimiento de Labeko Koba (Arrasate, País Vasco). In: Labeko Koba (País Vasco): Hienas y Humanos en los albores del Paleolítico superior (Arrizabalaga, Á. \& Altuna, J., Eds.), Munibe Vol. 52, p. 345-354. (in Spanish) ("Provenance analysis of the chert from the site of Labeko Koba (Arrasate, Basque Country)")

URL: http://www.aranzadi.eus/fileadmin/docs/Munibe/2000345354AA.pdf 
Tarriño, A. 2006, El sílex en la cuenca vasco-cantábrica y Pirineo navarro: caracterización y su aprovechamiento en la Prehistoria. Monografías del Museo Nacional y Centro de Investigación de Altamira Vol. 21, Minesterio de Educación y Cultura, Madrid, 263 p. (in Spanish) ("Flint in the Basque-Cantabrian basin and the Pyrenees Navarro: characterization and its use in prehistory")

Tarriño, A. 2011a, Procedencia de los sílex de la cueva de Aitzbitarte-III (Rentería, Gipuzkoa). In: Ocupaciones humanas en Aitzbitarte III (País Vasco) 33.600-18.400 BP (Altuna, J., Mariezkurrena, K. \& Ríos, J., Eds.), EKOB Euskal Kultura Ondare Bilduma Vol. 5, Vitoria-Gasteiz: p. 353-373. (in Spanish) ("Provenance of flint from AitzbitarteIII Cave (Rentería, Gipuzkoa)")

Tarriño, A. 2011b, Procedencia de los sílex de la industria lítica del yacimiento en cueva de Santimamiñe. In: La cueva de Santimamiñe: Revisión y actualización (2004-2006) (López Quintana, J.C., Ed.), Diputación Foral de Bizkaia, Bilbao: p. 281-290. (in Spanish) ("Provenance of flint from Santimamiñe cave (Kortezubi, Bizkaia)")

Tarriño, A., Bon, F. \& Normand, C. 2007a, Disponibilidad del Sílex como materia prima en la Prehistoria del Pirineo occidental. In: Frontières culturelles dans les Pyrénées préhistoriques (Cazals, N., González Urquijo, J. \& Terradas, X., Eds.), PubliCanEdiciones de la Universidad de Cantabria, Cantabria: p. 103-123. (in Spanish) ("The availability of flint as raw material in the western Pyrenees Prehistory")

Tarriño, A., Cava, A. \& Barandiarán, I. 2013, Recursos líticos en las industrias del Solutrense Cantábrico: El caso de Altamira (Cantabria, España). Revue Archéologique du Centre de la France 21: 261-272. (in Spanish) ("Lithic resources in the Cantabrian Solutrean assemblages: The Altamira case (Cantabria, Spain)")

Tarriño, A. \& Elorrieta, I. 2013, La explotación de los recursos abióticos durante el Gravetiense cantábrico. Primeros datos sobre el Pirineo occidental y la cuenca vascocantábrica. In: Pensando el Gravetiense: Nuevos datos para la región cantábrica en su contexto peninsular y pirenáico (de las Heras, C., Lasheras, J.A., Arrizabalaga, A. \& de la Rasilla, M., Eds.) Monografías del Museo Nacional y Centro de Investigación de Altamira Vol. 23, Ministerio de Educación y Cultura, Madrid: p. 330-347. (in Spanish) ("Exploitation of abiotic resources during the Cantabrian Gravettian. First data in Western Pyrenees and Basque-Cantabrian Bassin")

Tarriño, A., Elorrieta, I. \& García-Rojas, M. 2015, Flint as raw material in prehistoric times: Cantabrian Mountain and Western Pyrenees data. Quaternary International, 364: 94108. doi:10.1016/j.quaint.2014.10.061

Tarriño, A. \& Normand, C. 2002, Procedencia de los restos líticos en el Auriñaciense antiguo (C 4b1) de Isturitz (Pyrénées-Atlantiques, Francia). Espacio, Tiempo y Forma, Serie I, nueva época Prehistoria y Arqueología, 15: 135-143. (in Spanish) ("Provenance of lithic assemblage in the Ancient Aurignacien (C 4b1) from Isturitz (PyrénéesAtlantiques, France)") doi:10.5944/etfi.15.2002.4741

Tarriño, A., Olivares, M., Etxebarria, N., Baceta, J.I., Larrasoaña, J., Yusta, I., Pizarro, J., Cava, A., Barandiarán, I. \& Murelaga, X. 2007b, El sílex de tipo "Urbasa": Caracterización petrológica y geoquímica de un marcador litológico en yacimientos arqueológicos del Suroeste europeo durante el Pleistoceno superior y Holoceno inicial. Geogaceta, 43: 127-130. (in Spanish) ("The “Urbasa” type flint. Main petrological and geochemical features of a lithological marker in late Pleistocene and earliest Holocene archaeological sites") URI: http://hdl.handle.net/10272/8355 
Terradas, X. 2002, La gestión de los recursos minerales en las sociedades cazadorasrecolectoras. Treballs D’Etnoarqueologia, Vol. 4, Consejo Superior de Investigaciones Cienti ficas, Madrid, 177 p. (in Spanish) ("The management of mineral resources in hunter-gatherer societies")

Tobler, W. 1993, Three presentations on geographical analysis and modeling. Technical Report Vol. 93, Issue 1, National Center for Geographic Information \& Analysis (U.S.), University of California, Santa Barbara, California.

URL: http://www.ncgia.ucsb.edu/Publications/Tech_Reports/93/93-1.PDF

Turrero, P., Domínguez-Cuesta, M.J., Jiménez-Sánchez, M. \& García-Vázquez, E. 2013, The spatial distribution of Palaeolithic human settlements and its influence on palaeoecological studies: a case from Northern Iberia. Journal of Archaeological Science, 40(12): 4127-4138. doi:10.1016/j.jas.2013.06.003

van Leusen, P.M. 2002, Pattern to Process: Methodological Investigations into the Formation and Interpretation of Spatial Patterns in Archaeological Landscapes. Ph.D. dissertation. Institute of Archaeology, University of Groningen, Groningen, 356 p.

Vialou, D. 2005, Territoires: sédentarités et mobilités. In: Comportements des hommes du Paléolithique moyen et supérieur en Europe: territoires et milieux (Vialou, D., RenaultMiskovsky, J. \& Patou-Mathis, M., Eds.) ERAUL 111, Université de Liège, Liège: p. 75-86. (in French) ("Behavior of Middle and Upper Palaeolithic human in Europe: territories and environments")

Whallon, R. 2006, Social networks and information: non-"utilitarian” mobility among huntergatherers. Journal of Anthropological Archaeology, 25: 259-279. doi:10.1016/j.jaa.2005.11.004

Wheatley, D. \& Gillings, M. 2002, Spatial Technology and Archaeology: The Archaeological Applications of GIS. Taylor \& Francis, New York, 269 p.

White, D. \& Surface-Evans, S. (Eds) 2012, Least Cost Analysis of Social Landscapes: Archaeological Case Studies. The University of Utah Press, Salt Lake City, 268 p. 